\title{
Antioxidant potential and physicochemical properties of protein hydrolysates from body parts of North Atlantic sea cucumber (Cucumaria frondosa)
}

\author{
Tharindu R. L. Senadheera ${ }^{1}$, Deepika Dave ${ }^{1,2^{*}}$ and Fereidoon Shahidi ${ }^{1 *}$ (D)
}

\begin{abstract}
Protein hydrolysates were prepared from North Atlantic sea cucumber (Cucumaria frondosa) body wall (BW), and processing by-product flower (FL) and internal organs (IN). Sea cucumber proteins from these three tissues were hydrolysed with selected endopeptidases and exopeptidases. The enzymes used were Alcalase (A), and Corolase (C) as endopeptidases and Flavourzyme (F) with both endo- and exopeptidase functions. These were employed individually or in combination under controlled conditions. The hydrolysates so prepared were subsequently analysed for their antioxidant potential and functionalities in food systems for the first time. Hydrolysates treated with the combination of $\mathrm{A}$ and $\mathrm{F}$ exhibited the highest radical scavenging activity against DPPH and ABTS radicals. The highest metal chelation activity was observed for samples hydrolysed with the combination of enzymes $(\mathrm{C}+\mathrm{F}$ and $\mathrm{A}+\mathrm{F})$. All treatments inhibited beta-carotene bleaching in an oil-in-water emulsion and TBARS production in a meat model system. In addition, sea cucumber protein hydrolysates were more than 75\% soluble over a pH range of 2-12. Hydrolysed proteins were also effective in enhancing water holding capacity in a meat model system compared to their untreated counterparts. The amino acids of sea cucumber protein hydrolysates had desirable profiles with glutamic acid as the predominant component in samples analysed. These findings demonstrate the desirable functionalities of hydrolysates from North Atlantic sea cucumber and their potential for use as functional food ingredients.
\end{abstract}

Keywords: Sea cucumber, Protein hydrolysates, Antioxidant activity, Physicochemical properties

\section{Introduction}

The Atlantic sea cucumber Cucumaria frondosa which belongs to the phylum Echinodermata is one of the most abundant holothuroids found in the waters of North Atlantic (Hossain et al. 2020). These cylindershaped invertebrates are rich in nutrients with high protein, vitamin and mineral content as well as being low in fat (Zhong et al. 2007; Senadheera et al. 2020). Sea cucumbers have long been used as an important

\footnotetext{
* Correspondence: Deepika.Dave@mi.mun.ca; fshahidi@mun.ca

'Department of Biochemistry, Memorial University of Newfoundland, St. John's, NL A1B 3X9, Canada

Full list of author information is available at the end of the article
}

marine food source with remarkable nutraceutical value mainly in the Indo-Pacific region from decades. They have been widely known as a traditional food ingredient and a dietary supplement. However, sea cucumber fishery in North Atlantic provinces in Canada is as emerging fishery and remains to be explored for its maximum commercial potential (Hossain et al. 2020). Sea cucumbers are mainly harvested for their body wall and that is relatively thin in Cucumaria frondosa compared to other commonly harvested sea cucumber species (Nelson et al. 2012). Nevertheless, Cucumaria frondosa is marketable for its longitudinal internal muscle bands and dried body wall in the Asian food

(c) The Author(s). 2021 Open Access This article is licensed under a Creative Commons Attribution 4.0 International License, which permits use, sharing, adaptation, distribution and reproduction in any medium or format, as long as you give

appropriate credit to the original author(s) and the source, provide a link to the Creative Commons licence, and indicate if changes were made. The images or other third party material in this article are included in the article's Creative Commons licence, unless indicated otherwise in a credit line to the material. If material is not included in the article's Creative Commons licence and your intended use is not permitted by statutory regulation or exceeds the permitted use, you will need to obtain permission directly from the copyright holder. To view a copy of this licence, visit http://creativecommons.org/licenses/by/4.0/ 
market (Tripoteau et al. 2015). The remaining tissues after processing of sea cucumber include aquapharyngeal bulb (flower) and internal organs such as digestive tract, gonads, and respiratory tree which are usually discarded (Mamelona et al. 2010a; Tripoteau et al. 2015). This generates a large volume of biological waste which accounts for approximately $50 \%$ of the total biomass of the Atlantic sea cucumber (Mamelona et al. 2010b). These by-products have the potential to be used for production of bioactive molecules which could be employed as value added ingredients in different applications. However, compared to other echinoderm species, by-products from Cucumaria frondosa are not yet fully explored.

Marine by-products are rich protein sources for production of protein hydrolysates and peptides with unique bioactive properties (Shahidi et al. 2019). The most common ways of producing protein hydrolysates in the industrial sector include chemical and biological means (Kristinsson and Rasco 2000). Production of protein hydrolysates using enzyme hydrolysis has received growing attention as an effective method to produce functional food ingredients and nutraceuticals for disease risk reduction and health promotion (Girgih et al. 2013; Ambigaipalan et al. 2015). The most frequently used enzymes are derived from plants, animals and microbial sources (Kristinsson and Rasco 2000; Rodríguez-Vázquez et al. 2020). However, microbial proteases such as Alcalase, Flavourzyme, and Corolase are popular in industrial production due to their favourable operational conditions (Kristinsson and Rasco 2000). In addition, enzymatic modification of proteins is mainly determined by the type of enzyme used in the hydrolysis process (Udenigwe and Aluko 2012). Different types of proteinases, including endo- and exo- proteinases are used to hydrolyze peptide linkages. Endopeptidases hydrolyse the peptide bonds between polypeptide chains, while exopeptidases (aminopeptidase and carboxypeptidase) catalyze the cleavage of the terminal peptide bonds in a polypeptide chain or protein (Ambigaipalan and Shahidi 2017).

Functionality and the bioactivity of hydrolysed food proteins are due to the peptides that contain 2-20 amino acid units (Shahidi and Zhong 2008; Udenigwe and Aluko 2012). Molecular weight, amino acid sequence, hydrophobic and polar groups of the peptides determine the biological activity and functional properties of the hydrolysed product (Xu et al. 2019). Numerous studies have been conducted on the preparation of hydrolysates from different protein sources including marine organisms and their by-products such as capelin (Shahidi, Shahidi et al. 1995; Amarowicz and Shahidi 1997), shrimp shells (Ambigaipalan and Shahidi 2017), sardine, mackerel, bogue and small- spotted catshark (García-Moreno et al. 2014), and blue-spotted stingray (Wong et al. 2019), among others.

In contrast, very limited number of studies have reported the bioactive potential of Atlantic sea cucumber by-products including antiviral activities of flower and internal organs (Tripoteau et al. 2015), antioxidant activities (Mamelona et al. 2010a) and functional properties (Yan et al. 2016) of viscera. Few of the recent studies have been focused on the hydrolysis of the whole animal to examine the potential of using hydrolysates as antiaging agents (Lin et al. 2018) and identification of antioxidative peptides (Zhang et al. 2020). To the authors'best knowledge, enzymatic hydrolysates of different tissues of $\mathrm{Cucu}$ maria frondosa have not been comparatively studied to assess their potential in radical scavenging activity, chelating ability of prooxidant transition metal ions and their antioxidative properties in various food model systems including cooked comminuted meat and oil-in water emulsion systems. Moreover, there is no report available on determining the effect of sequential use and individual endopeptidases and exopeptidases on the production of protein hydrolysates from Atlantic sea cucumber discards. Therefore, this is the first study in the field of utilizing different body parts of the Atlantic sea cucumber Cucumaria frondosa for the production of protein hydrolysates using Alcalase and Corolase as exopeptidases and Flavourzyme with both endopeptidase and exopeptidase activity and investigates their antioxidant potential in food model systems.

\section{Materials and methods Materials}

Fresh sea cucumbers (Cucumaria frondosa) were harvested from Northwest and Southeast regions of the St. Pierre Bank (NAFO Division 3Ps), Newfoundland, Canada. Alcalase (2.4 AU/ g) and Flavourzyme (1000 LAPU/g) were purchased from Novozymes, Bagsvaerd, Denmark. Corolase 7089 was procured from AB enzymes $\mathrm{GmbH}$, Darmstadt, Germany. All chemicals and solvents used were of analytical or chromatographic grade and were obtained from Sigma-Aldrich Canada Ltd. (Oakvillie, ON, Canada) or Fisher Scientific Ltd. (Ottawa, ON, Canada).

\section{Methods \\ Preparation of protein hydrolysates}

Fresh sea cucumbers were dissected and separated into body wall (BW), flower (FL), and internal organs (IN). Tissues of separated body parts were freezedried using a Labconco FreeZone benchtop freeze dryer (Labconco, Kansas City, MO, USA) (Fig. 1). 


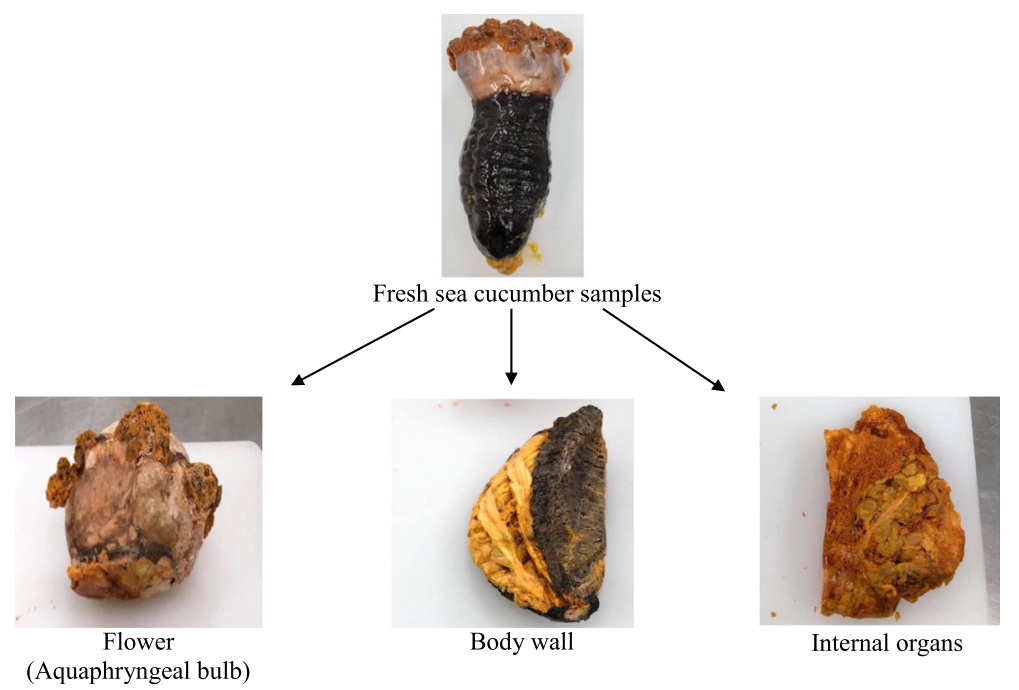

Fig. 1 Sea cucumber sample preparation

Dried samples were ground to particle size $\leq 100 \mu \mathrm{m}$. The fine powder so obtained was then defatted according to Ambigaipalan and Shahidi (2017) and proteins were isolated using $\mathrm{pH}$ shifting method. Isolated proteins were hydrolyzed with enzymes according to the preselected ratio of enzyme to protein for each treatment $(0.3 \mathrm{AU} / \mathrm{g}$ for Alcalase; $50 \mathrm{LAPU} / \mathrm{g}$ for Flavourzyme and $840 \mathrm{UHb} / \mathrm{g}$ for Corolase 7089). The samples were hydrolysed batchwise with Alcalase (A, $\left.\mathrm{pH} 8,50^{\circ} \mathrm{C}\right)$ for $4 \mathrm{~h}$, Flavourzyme $\left(\mathrm{F}, \mathrm{pH} 7,50^{\circ} \mathrm{C}\right)$ for $4 \mathrm{~h}$, and Corolase $7089\left(\mathrm{C}, \mathrm{pH} 8,52^{\circ} \mathrm{C}\right)$ for $4 \mathrm{~h}$. Enzyme combination treatments were conducted by hydrolysing first with Corolase for $2 \mathrm{~h}\left(\mathrm{pH} 8,52^{\circ} \mathrm{C}\right)$ followed by adding Flavourzyme $\left(\mathrm{pH} 7,50^{\circ} \mathrm{C}\right)$ for an additional $2 \mathrm{~h}$. Similar sequential addition were conducted for Alcalase and Flavourzyme, where samples were hydrolysed with Alcalase for $2 \mathrm{~h}\left(\mathrm{pH} 8,50^{\circ} \mathrm{C}\right)$, followed by the addition of Flavourzyme for $2 \mathrm{~h}(\mathrm{pH} 7$, $50{ }^{\circ} \mathrm{C}$ ). Conditions were constantly monitored and maintained throughout the process by the addition of $4 \mathrm{M} \mathrm{NaOH}$. Upon completion of the incubation periods, the reactions were terminated by heating the mixture at $90^{\circ} \mathrm{C}$ for $10 \mathrm{~min}$ to inactivate the enzyme. The degree of hydrolysis ( $\mathrm{DH}, \%)$ was determined by the TNBS (trinitrobenzenesulfonic acid acid) method (Adler-Nissen 1979). The hydrolysates were centrifuged at $10,000 \mathrm{~g}$ for $15 \mathrm{~min}$ and the recovered supernatants were freeze-dried and stored at $-20{ }^{\circ} \mathrm{C}$ until further analysis. Figure 2 represents the experimental design for evaluating the antioxidant potential of sea cucumber protein hydrolysates.

\section{DPPH radical scavenging activity for protein hydrolysates}

The DPPH (2,2-diphenyl-1,1-picrylhydrazyl) radical scavenging activity was determined using a Bruker-Escan electron paramagnetic resonance (EPR) spectrometer (Bruker E-scan, Bruker Biospin Co., Billericia, MA, USA) according to the method described by Chandrasekara and Shahidi (2011), with minor modifications. Protein hydrolysates $(250 \mu \mathrm{L}, 0.5 \mathrm{mg} / \mathrm{mL})$ were added to $1 \mathrm{~mL}$ of $0.3 \mathrm{mM} \mathrm{DPPH}$ methanolic solution. The mixture was immediately homogenized and incubated in the dark for $30 \mathrm{~min}$ at room temperature. Then, the mixtures $(1 \mathrm{~mL})$ were introduced into the sample cavity of the EPR spectrometer and the spectrum was recorded after $10 \mathrm{~min}$. Trolox was used to prepare the standard curve $(50-500 \mu \mathrm{M}$ in methanol). The operating parameters of the EPR spectrometer were set as follows: $1.86 \mathrm{G}$ modulation amplitude, $5.02 \times 10^{2}$ receiver gain, $2.621 \mathrm{~s}$ sweep time, 8 scans, $100.00 \mathrm{G}$ sweep width, $3495.53 \mathrm{G}$ center field, $5.12 \mathrm{~ms}$ time constant, $9.795 \mathrm{GHz}$ microwave frequency, $1.86 \mathrm{G}$ modulation amplitude, and 86.00 $\mathrm{kHz}$ modulation frequency. DPPH radical scavenging capacity, expressed as millimoles $(\mathrm{mM})$ of Trolox equivalents (TE) per gram of protein hydrolysate, was calculated according to Eq. 1.

$$
\begin{gathered}
\text { DPPH radical } \\
\text { scavenging capacity }(\%)
\end{gathered}=\frac{(\text { EPR signal intensity for the control }- \text { EPR signal for the sample })}{\text { EPR signal intensity for the control }} \times 100
$$




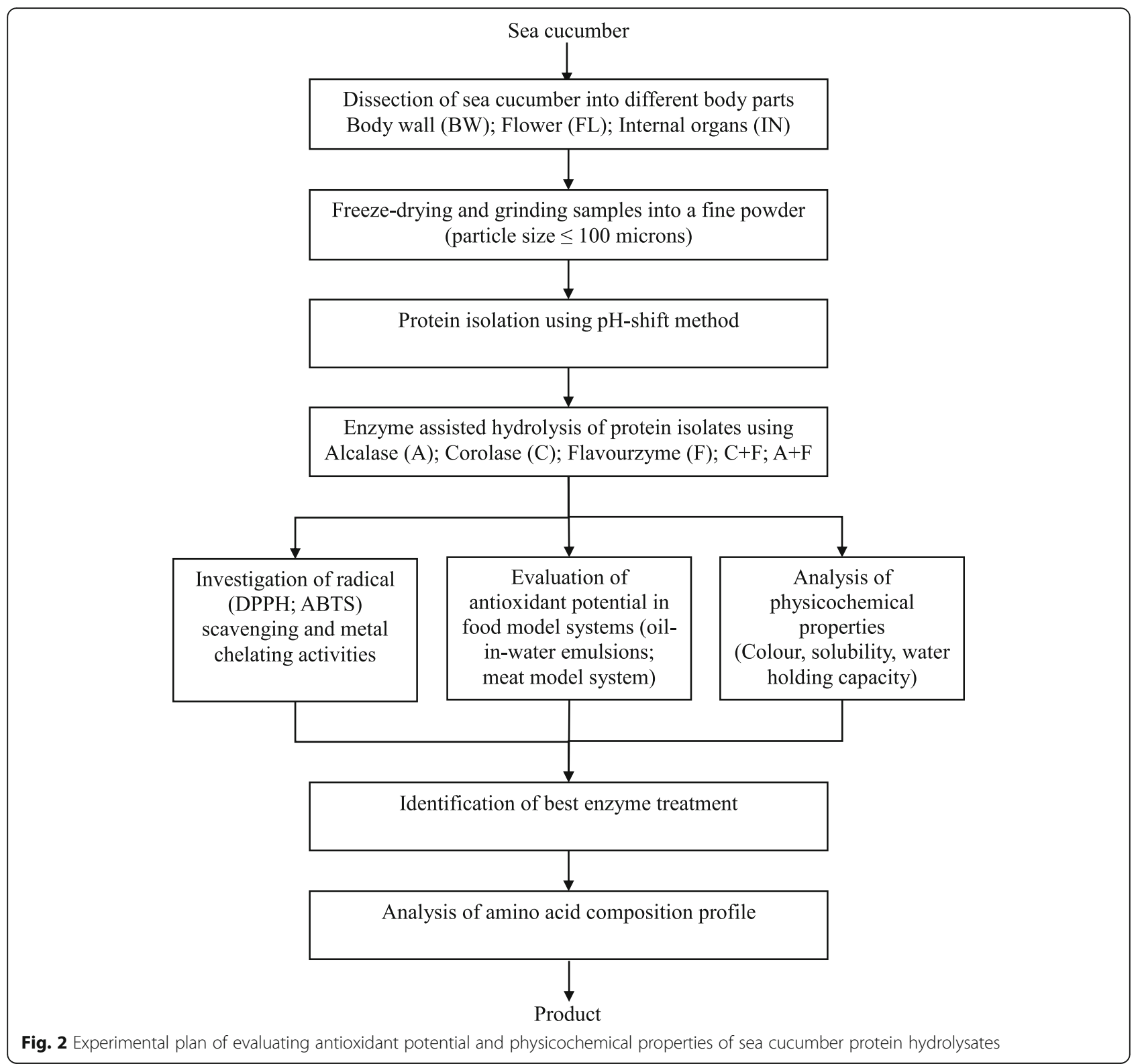

\section{ABTS radical scavenging activity for protein hydrolysates}

The 2,2'-azinobis (3-ethylbenzothiazoline-6-sulfonate) radical cation $\left(\mathrm{ABTS}^{*+}\right.$ ) scavenging activity of protein hydrolysates was determined as described by John and Shahidi (2010). The protein hydrolysates and reagents were prepared in $100 \mathrm{mM}$ phosphate buffer (PBS) containing $0.15 \mathrm{M} \mathrm{NaCl}$ (pH 7.4). ABTS solution was prepared by mixing $2.5 \mathrm{mM} \mathrm{2,2}$-azobis-(2-methylpropionamidine) dihydrochloride (AAPH) with $2.5 \mathrm{mM}$ ABTS in a 1:1(v/v) ratio. The mixture was heated for $20 \mathrm{~min}$ at $60^{\circ} \mathrm{C}$ and stored in the dark at room temperature. Protein hydrolysates $(40 \mu \mathrm{L}, 1 \mathrm{mg} / \mathrm{mL})$ were mixed with the ABTS solution $(1.96 \mathrm{~mL})$ and the mixture was allowed to react for $6 \mathrm{~min}$ prior to reading the absorbance at $734 \mathrm{~nm}$. Blank was prepared in the same manner using distilled water instead of sample. A standard curve was constructed using different concentrations of Trolox $(0-1000 \mu \mathrm{M})$. The ABTS radical scavenging activity, expressed as micromoles $(\mu \mathrm{M})$ of Trolox equivalents (TE) per gram of protein hydrolysates was calculated according to Eq. 2.

$\begin{gathered}\text { ABTS radical } \\ \text { scavenging ability }(\%)\end{gathered}=\frac{(\text { Absorbance of the blank }- \text { Absorbance of the sample after } 6 \mathrm{~min})}{\text { Absorbance of the blank }} \times 100$ 


\section{Metal chelation activity}

Ferrous ion chelating activity was determined according to the method of Chandrasekara and Shahidi (2011), with minor modifications. Two hundred microliters of sea cucumber protein hydrolysates $(0.5 \mathrm{mg} / \mathrm{mL})$ were mixed with $1.74 \mathrm{~mL}$ of distilled water, $20 \mu \mathrm{L}$ of $\mathrm{FeCl} 2(2$ $\mathrm{mM})$ and $40 \mu \mathrm{L}$ of ferrozine $(5 \mathrm{mM})$ and incubated at room temperature for $10 \mathrm{~min}$. The absorbance was recorded at $562 \mathrm{~nm}$. The control was prepared using distilled water and a standard curve was built using trisodium salt of ethylenediaminetetraacetic acid $\left(\mathrm{Na}_{3} \mathrm{EDTA}\right)$. Metal ion chelating activity (\%) was calculated using Eq.3.

Metal ion chelation activity $(\%)=\left\{1-\left(\frac{\text { Absorbance of the sample }}{\text { Absorbance of the control }}\right)\right\} \times 100$

\section{Antioxidant activity in cooked comminuted meat model system}

The cooked comminuted meat model system was prepared according to the method of Wettasinghe and Shahidi (1999). Fresh comminuted meat (40 g) was mixed with $10 \mathrm{~mL}$ of distilled water in a Mason jar and protein hydrolysates $(200 \mathrm{ppm})$ were added to the mixture. Butylated hydroxytoluene (BHT) was used as a positive control and a negative control (no protein hydrolysates) was also prepared. All samples were cooked in a thermostatic water bath $\left(80^{\circ} \mathrm{C}\right)$ for $40 \mathrm{~min}$ with gentle stirring every $5 \mathrm{~min}$. The samples were cooled to room temperature prior to being transferred into plastic bags for storage at $4{ }^{\circ} \mathrm{C}$. Samples were randomly taken out according to designated time interval $(0,3,5,7,10$, and 14 days) for analysis of thiobarbituric acid reactive substances (TBARS) described by Wijeratne et al. (2006). The TBARS values were calculated using a standard curve of malondialdehyde (MDA), using MDA precursor, and expressed as mg MDA equivalents per kilogram of sample.

\section{Antioxidant activity in oil-in-water emulsions}

The antioxidant activity of protein hydrolysates in oil-inwater emulsion was evaluated using a $\beta$-carotene-linoleate model system according to the method described by Ambigaipalan and Shahidi (2015). Briefly, $10 \mathrm{mg}$ of $\beta$-carotene were dissolved in $10 \mathrm{~mL}$ of chloroform. Then, $1.2 \mathrm{~mL}$ of the $\beta$-carotene solution was pipetted into a $50 \mathrm{~mL}$ roundbottom flask which contained linoleic acid $(40 \mathrm{mg})$ and Tween $40(400 \mathrm{mg})$. Chloroform was subsequently removed under a stream of nitrogen before the addition of oxygenated distilled water $(100 \mathrm{~mL})$ to the flask. The mixture was then vigorously stirred for $30 \mathrm{~min}$ and an aliquot of $4.5 \mathrm{~mL}$ was mixed with $0.5 \mathrm{~mL}$ of protein hydrolysate $(0.5 \mathrm{mg} / \mathrm{mL}$ in distilled water). For each sample, a blank was prepared without $\beta$-carotene and a control without protein hydrolysates was also prepared. Trolox (100 ppm) was used as a positive control. Immediately after the addition of the emulsion, the absorbance was read at 470 $\mathrm{nm}$. The tubes were then placed in a shaking water bath $\left(50^{\circ} \mathrm{C}\right)$ and the absorbance was continuously read over a $105 \mathrm{~min}$ period at $15 \mathrm{~min}$ intervals. Antioxidant activity of protein hydrolysates in an oil-in-water emulsion system was calculated according to Eq. 4.

$$
\text { Antioxidant activity }(\%)=\left[\frac{\left(\mathrm{A}_{0}-\mathrm{A}_{\mathrm{t}}\right)}{\left(\mathrm{A} 0_{0}-\mathrm{A} 0_{\mathrm{t}}\right)}\right] \times 100
$$

where $A_{0}$ and At are corrected absorbance values for protein hydrolysates at time 0 and after incubation, and $\mathrm{AO}_{0}$ and $\mathrm{AO}_{\mathrm{t}}$ are absorbance value for the control at time $\mathrm{t}$ and after incubation, respectively.

\section{Colour measurement of freeze-dried protein hydrolysates}

The colour of the freeze-dried protein hydrolysate was measured by Hunter lab colour meter (Hunter Associates Laboratory Inc., Reston, VA, USA) and reported using CIE system, where $\mathrm{L}$, a and b parameters indicate lightness, redness and yellowness, respectively.

\section{Solubility of protein hydrolysates}

The solubility of protein hydrolysates was determined at different $\mathrm{pH}$ values, following the method described by Ambigaipalan and Shahidi (2015) with slight modifications. Protein hydrolysates were dispersed in distilled water to obtain the final concentration of $10 \mathrm{mg}$ protein/ $\mathrm{mL}$. The $\mathrm{pH}$ of each dispersion was adjusted to $2,5,8$, and 12 by adding $1 \mathrm{M} \mathrm{HCl}$ and $1 \mathrm{M} \mathrm{NaOH}$. Mixtures were stirred for $30 \mathrm{~min}$ and centrifuged at $7500 \mathrm{~g}$ for $15 \mathrm{~min}$. The protein content in the supernatants was analysed using the biuret method. Total protein content was determined after solubilization of the sample in $0.5 \mathrm{M} \mathrm{NaOH}$.

$$
\text { Protein Solubility }(\%)=\frac{\text { Protein content in Supernatant }}{\text { Total Protein content in sample }} \times 100
$$

\section{Determination of water holding capacity of protein hydrolysates using a meat model system}

The water holding capacity of sea cucumber protein hydrolysates was evaluated according to the method reported by Shahidi et al. (1995). Ground pork $(8.5 \mathrm{~g})$ and distilled water $(1.5 \mathrm{~g})$ were mixed in a pre-weighed 50 $\mathrm{mL}$ centrifuge tube to prepare the meat model system. Sea cucumber protein hydrolysates were added to the system and mixed thoroughly. A control was prepared devoid of any sample whereas sodium tripolyphosphate was used as a positive control. The mixture was placed in a cold room for $1 \mathrm{~h}$ before cooking at $95^{\circ} \mathrm{C}$ in a water 
bath for $1 \mathrm{~h}$. The cooked homogenates were cooled under a stream of cold tap water and, subsequently, the drip volume was measured using a filter paper. The final weight of the homogenate was recorded, and the drip volume was determined using the weight loss of the meat model after cooking. The water holding capacity of protein hydrolysates was reported as decrease of drip volume against the control.

\section{Amino acid composition analysis}

The amino acid composition of each protein hydrolysates was analysed at the Analytics, Robotics and Chemical Biology Centre (SPARC BioCentre, The Hospital for Sick Children, Toronto, ON, Canada) as reported by Mohan and Udenigwe (2015). Except for tryptophan, cysteine and methionine analysis, all the other amino acids were analysed using vapour-phase hydrolysis with $6 \mathrm{M} \mathrm{HCl}, 1 \%$ phenol at $110^{\circ} \mathrm{C}$ for $24 \mathrm{~h}$. For tryptophan analysis, samples were hydrolysed with $4.2 \mathrm{M} \mathrm{NaOH}$ for $24 \mathrm{~h}$ at $110^{\circ} \mathrm{C}$. Cysteine and methionine quantifications were carried out by performic acid oxidation prior to hydrolysis. Norleucine $(25 \mu \mathrm{M} / \mathrm{mL})$ was used as internal standard for all samples. Following hydrolysis, samples were dried and resuspended in a redrying solution of methanol/ water/ triethylamine $(2: 2: 1, \mathrm{v} / \mathrm{v} / \mathrm{v})$ and vacuum dried for $15 \mathrm{~min}$. This was followed by pre-column derivatization with a derivatizing solution made up of methanol/ water: /triethylamine/ phenyl isothiocyanate (PITC) $(7: 1: 1: 1, \mathrm{v} / \mathrm{v} / \mathrm{v} / \mathrm{v})$. The derivatized samples were vacuum dried and dissolved in sample diluent. Diluent aliquots were then analysed by a high performance liquid chromatography system, Waters ACQUITY UPLC (Milford, MA, USA) consisting of a 10-cm C-18 column $(0.21 \times 10 \mathrm{~cm})$ running on a modified PICO-TAG gradient at $48{ }^{\circ} \mathrm{C}$. The amino acids were quantified based on the peaks monitored at $254 \mathrm{~nm}$ with a UV detector.

\section{Statistical analysis}

All the experiments were carried out in triplicates and data were reported as mean \pm standard deviation. Oneway ANOVA was performed, and means were compared by Tukey's HSD test $(p<0.05)$ using SPSS 16.0 for Windows (SPSS Inc., Chicago, IL, USA).

\section{Results and discussion}

\section{Degree of hydrolysis (DH)}

The degree of hydrolysis is an important parameter that can have a direct influence on biological function of peptides (Xie et al. 2019). Defatted sea cucumber samples, hydrolysed with Alcalase (A), Flavourzyme (F) and Corolase $(\mathrm{C})$, showed a similar pattern for degree of hydrolysis. Hydrolysis curves (Fig. 3) show the DH (\%) obtained for the hydrolysates produced from sea cucumber body wall (BW), flower (FL) and internal organs (IN) up to 4 $h$ of hydrolysis. The increase in the hydrolysis of proteins was observed in BW, FL and IN for first $2 \mathrm{~h}$. After $4 \mathrm{~h}$ of hydrolysis with Alcalase, Flavourzyme and Corolase, DH values ranged between 6 and 13\%, 5 and $8 \%$ in internal organs and 5 and $12 \%$ in body wall, flower and internal organs, respectively (Fig. 2). The highest $\mathrm{DH}$ values in individual enzyme treatment was observed for Alcalase treated samples in each tissue (BWA $13.5 \%$; INA $~ 8.5 \%$; FLA 12.5\%). Nearly the same of $\mathrm{DH}$ was obtained for samples which were individually treated with Corolase and Flavourzyme in body wall hydrolysates (BWF 9.5\%; BWC 10.7\%) after $4 \mathrm{~h}$ of hydrolysis. A similar trend was observed in flower hydrolysates (FLF 11.7\%; FLC 10.6\%) and hydrolysates prepared from internal organs (INF 6.5\%; INC 6.2\%) during the same hydrolysis time. Similar findings were reported by Mamelona et al. (2010a) for Alcalase assisted hydrolysis of sea cucumber viscera (5.6\%) and Yan et al. (2016). Under optimum hydrolysis conditions sea cucumber viscera was treated with Alcalase for $6 \mathrm{~h}$ showed higher $\mathrm{DH}$ value than Flavourzyme assisted hydrolysis (Yan et al. 2016).

After an initial rapid phase, the rate of hydrolysis reached a stationary phase (Ambigaipalan and Shahidi 2017). The rapid hydrolysis indicates that a large number of peptide bonds was hydrolyzed in the initial phase (Shahidi et al. 1995). The stationary phase may correlate with the decrease in hydrolysis sites, enzyme autodigestion or product inhibition (Khantaphant and Benjakul 2008). Thus, increasing the concentration of specific enzymes may not be effective for obtaining a higher degree of hydrolysis. The typical hydrolysis curves were also reported for thronback ray fish (Lassoued et al. 2015), sardinella (Ben Khaled et al. 2014) and zebra blenny (Ktari et al. 2012). Furthermore, protein hydrolysates with a degree of hydrolysis ranging from 1 to $10 \%$ have been reported to exhibit better functional properties than their precursor proteins (Panyam and Kilara 1996; Ambigaipalan et al. 2015). Extensive hydrolysis of protein may be detrimental to the quality of final products due to the exposure and accumulation of hydrophobic side chains of amino acids which may lead to bitterness (Ambigaipalan et al. 2015). The observed values for the $\mathrm{DH}$ of sea cucumber protein hydrolysates were in the same range as those reported for Atlantic salmon muscle hydrolysates produced using Alcalase, Flavourzyme and Corolase (Kristinsson and Rasco 2000) and shrimp hydrolysates produced with Alcalase and various other enzymes (Ambigaipalan and Shahidi 2017).

Among the single enzyme treatments, Alcalase showed the highest degree of hydrolysis in all three sea cucumber body parts. Alcalase is widely used to produce protein hydrolysates due to its proven ability to afford functional hydrolysates from fish protein (Shahidi and Synowiecki 


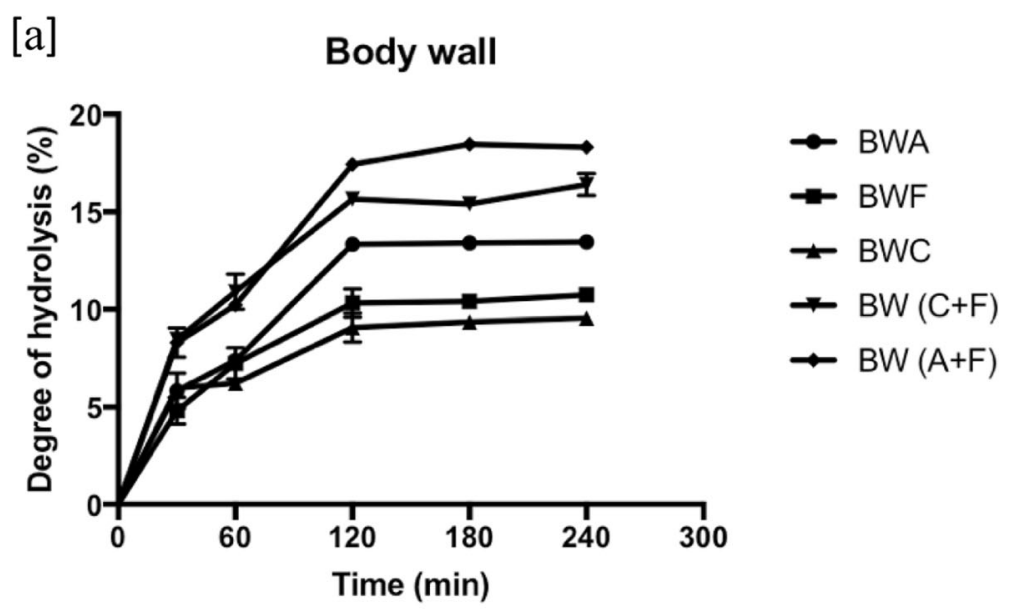

[b]

Flower
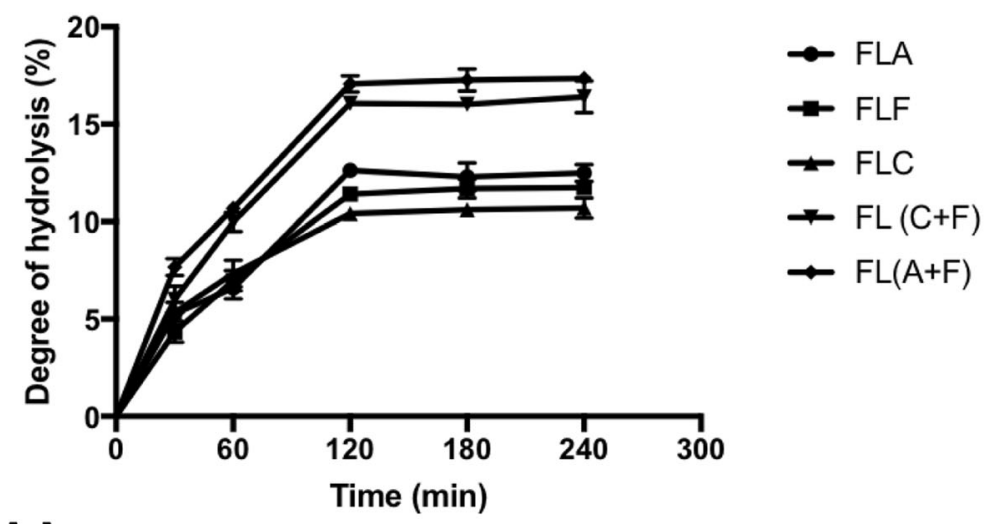

\section{$[\mathrm{c}]$}

\section{Internal organs}

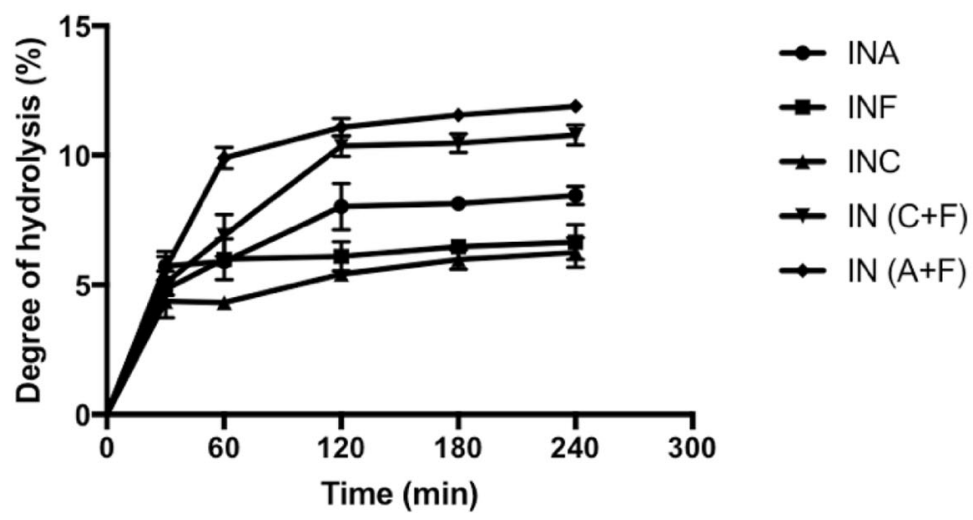

Fig. 3 Degree of hydrolysis (DH) of sea cucumber C. frondosa protein hydrolysates a BW, Body wall; b FL, Flower; and c IN, Internal organs; A, Alcalase; F, Flavourzyme; C, Corolase; C +F, Mixture of Corolase and Flavourzyme; and A+F, Mixture of Alcalase and Flavourzyme

1997; Kristinsson and Rasco 2000; Thiansilakul et al. 2007; Klompong et al. 2008). In addition, Flavourzyme and Corolase have also shown excellent potential for hydrolysing food proteins (Neves et al. 2017).

During hydrolysis, major structural changes in proteins are linked with the breaking down of polypeptide chains into smaller peptide units (Klompong et al. 2008;
Rao et al. 2020). In addition, use of a single enzyme for hydrolysis process shows relatively lower effectiveness than treatment with combinations of enzymes (Kristinsson and Rasco 2000). Villanueva et al. (1999) reported that sequential use of endopeptidase and exopeptidases could render a higher degree of hydrolysis and generate hydrolysates with better functional properties compared to single 
enzyme treatment. Hydrolysates obtained from using endopeptidase and exopeptidase sequentially exhibited significantly higher $(p<0.05) \mathrm{DH}$ values compared to that of single enzyme treated samples in all the three sea cucumber body parts. The observed DH values for combined Corolase and Flavourzyme treatment were $16,11.8$ and $17.3 \%$ for body wall, flower and internal organs, respectively. Reported DH values of the body wall, internal organs and flower hydrolysates prepared with combination of Alcalase and Flavourzyme were 18.3, 10.7 and $16.4 \%$, respectively. The observed trend was previously reported in several studies indicating that single enzyme application is not effective in bringing about extensive hydrolysis of food proteins (Rao et al. 2020; Xu et al. 2020). Variations in DH values could be attributed to the difference in specificity of enzymes during hydrolysis (Lassoued et al. 2015).

\section{DPPH radical scavenging activity}

When DPPH radical is scavenged by hydrolysates, certain amino acids or peptides present act as electron or hydrogen donors (Nalinanon et al. 2011; Shahidi and Yeo 2020). Furthermore, presence of hydrophobic amino acids in the hydrolysates makes the peptides more accessible to DPPH by increasing their solubility in a non-polar environment. This favours interaction of peptides with radicals and trap them in order to terminate the radical chain reaction (You et al. 2010). The radical scavenging ability of food proteins and their hydrolysates depend mainly on the various factors such as size and the amino acid composition of the peptides, specificity of the protease and DPPH assay conditions (Girgih et al. 2011).

DPPH radical scavenging of protein hydrolysates prepared from body wall, flower and internal organs were in the range of 10-14, 12-16 and 7-12 $\mu \mathrm{mol}$ of trolox/ $\mathrm{g}$ of protein, respectively (Fig. 4). Similar results were reported in the literature for protein hydrolysates from tilapia scale $(7.56 \mu \mathrm{mol}$ of trolox/g of protein) (Ngo et al. 2010), and shrimp shell protein hydrolysates (9.8$17.5 \mu \mathrm{mol}$ of trolox/ $\mathrm{g}$ of protein) (Ambigaipalan and Shahidi 2017). Moreover, DPPH radical scavenging activity of $C$. frondosa hydrolysates with different treatments exhibited different radical scavenging activities. However, as indicated in Fig. 3, no significant difference $(p>0.05)$ was observed in the internal organ hydrolysates treated with Flavourzyme, Corolase and two enzyme combinations. Similar trends were observed in the body wall and flower hydrolysates. In body wall, samples treated with Flavourzyme and samples treated with a combination of Alcalase and Flavourzyme exhibited no significant difference $(p>0.05)$ in DPPH radical scavenging activities whereas flower hydrolysates prepared with Flavourzyme, Corolase and their combination showed similar activity with no significant difference $(p>0.05)$ in scavenging of DPPH radicals. Furthermore, almost all samples treated with Flavourzyme or its combinations exhibited comparatively higher DPPH radical scavenging activity than other enzymes. Yan et al. (2016) suggested that hydrolysates prepared with Flavourzyme display high surface hydrophobicity and DPPH radical scavenging activity which is associated with the presence of hydrophobic amino acids or peptides. However, the difference in antioxidant activities among all treatments and the reported values could be attributed to the differences in amino acid compositions, sequence and their conformation (Girgih et al. 2011).

Flower hydrolysates prepared with a combination of Alcalase and Flavourzyme exhibited the highest DPPH radical scavenging activity among all treatments. Slizyte et al. (2016) reported similar findings for hydrolysates prepared from salmon backbones with combination of bromelain, papain and pepsin. They reported the highest DPPH radical activity in samples treated with a combination of enzymes compared to using single enzyme treatments. In addition, $\mathrm{He}$ et al. (2014) also revealed that anchovy protein hydrolysates prepared with endogenous enzymes combined with commercial proteases exhibited higher antioxidant activity than single enzyme treated samples.

The untreated counterparts of all tested body parts of sea cucumber $C$. frondosa, showed significantly lower $(p<0.05)$ DPPH radical scavenging activities compared to the samples hydrolysed with Alcalase, Flavourzyme and Corolase. These findings lend support to the report of Yan et al. (2016) on the radical scavenging activities of hydrolysates from the viscera of $C$. frondosa. The authors suggested that hydrolysates prepared with alkaline proteases such as Alcalase and Flavourzyme possess higher antioxidant activities than other tested enzymes including Neutrase, papain, bromelain and pepsin. They concluded that alkaline proteases are preferred for generating bioactive hydrolysates from sea cucumber samples (Yan et al. 2016).

Studies have shown that use of different enzymes for hydrolysing food proteins leads to varying antioxidant potentials in final products (Cumby et al. 2008). Furthermore, antioxidant capacity of each protein hydrolysate depends on its composition. For example, composition of Alcalase-assisted protein hydrolysates from flower may be completely different from that of Flavourzyme hydrolysates. This may account the varied antioxidant activities observed among the different enzyme treated sea cucumber hydrolysates.

\section{ABTS radical scavenging assay}

The ABTS assay measures the ability of antioxidants to scavenge the stable radical cation ABTS $\bullet+$, the blue/ green chromophore which has a maximum absorbance 


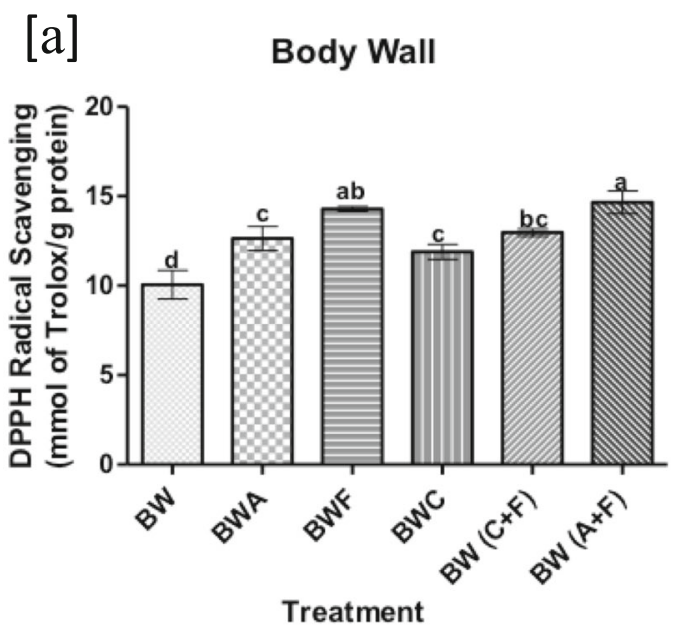

[b]

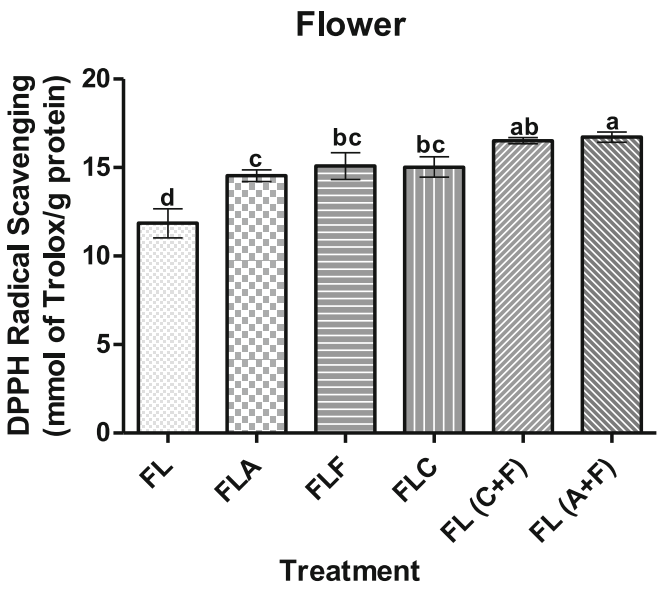

[c]

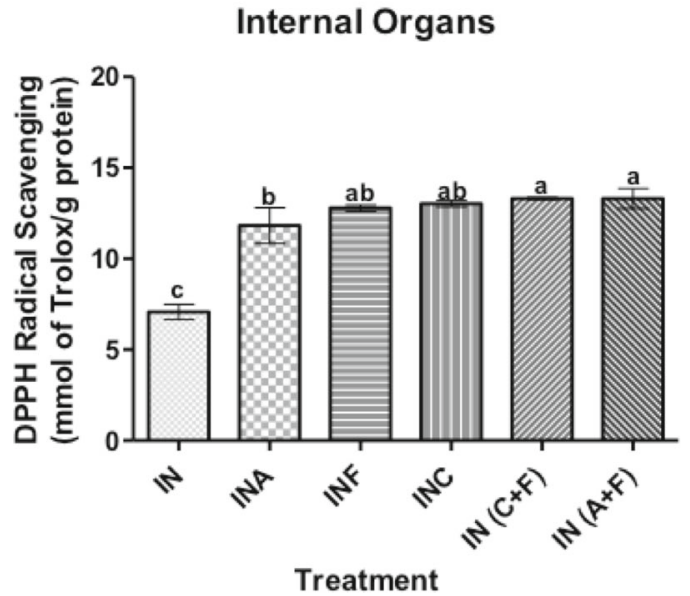

Fig. 4 DPPH radical scavenging activity of sea cucumber $C$. frondosa protein hydrolysates a BW, Body wall; b FL, Flower; and c IN, Internal organs; A, Alcalase; F, Flavourzyme; C, Corolase; C $+F$, Mixture of Corolase and Flavourzyme; and A $+F$, Mixture of Alcalase and Flavourzyme. Different letters for the same concentration of all hydrolysates indicates significant difference at $p<0.05$

at $734 \mathrm{~nm}$ (Shahidi and Zhong 2015). The chemical reaction between the strong oxidizing agent potassium persulfate produces the ABTS $\bullet+$ that can be neutralized by direct reduction or by radical quenching (Shahidi and Yeo 2020). Hence, this assay is based on single electron transfer (SET) as well as hydrogen atom transfer (HAT) mechanisms which can be used to determine both lipophilic and hydrophilic molecules (Ambigaipalan et al. 2015).

The ABTS radical scavenging activity of protein hydrolysates produced from different body parts of the sea cucumber showed significantly $(p<0.05)$ higher values than those of their untreated counterparts (Fig. 5). Hydrolysates of flower using sequential enzyme treatments of Alcalase and Flavourzyme exhibited the highest ABTS radical scavenging activity $(79.08 \pm 0.56 \mu \mathrm{mol}$ of trolox/g of protein) among all treated samples while the lowest activity $(17.79 \pm 0.81 \mu \mathrm{mol}$ of trolox/g of protein) was observed for the untreated internal organs sample. When considering overall ABTS radical scavenging activity of samples, protein hydrolysates produced from internal organs showed no significant difference $(p>$ 0.05 ) between samples treated with individual enzymes and enzyme combinations. The ABTS radical scavenging activity of sea cucumber samples were also similar to those of shrimp shell protein hydrolysates (Ambigaipalan and Shahidi 2017).

The trends observed for both ABTS and DPPH radical scavenging activity of the body wall and flower hydrolysates prepared by sequential treatment with Alcalase and Flavourzyme were similar. The difference between the hydrolysates produced by different enzymes dictates the antioxidant potential of the final products (Cumby et al. 2008).

These findings indicate that in addition to the degree of hydrolysis, free amino acids present after the hydrolysis process, as well as the amino acid sequence of the resultant peptides and their molecular weight could influence the radical scavenging activity of the peptides so produced (Intarasirisawat et al. 2012; Ambigaipalan et al. 2015). For instance, strong radical scavenging activities have been reported for tripeptides with tryptophan or tyrosine at their C-terminus. Moreover, difference in antioxidant potential of each sample may correlate with the different combinations of amino acids in the hydrolysed product (Saito et al. 2003). The difference in amino acid combinations of the resultant products is correlated with the hydrolysis of the polypeptides in various portions 


$$
\text { [a] }
$$

Body wall

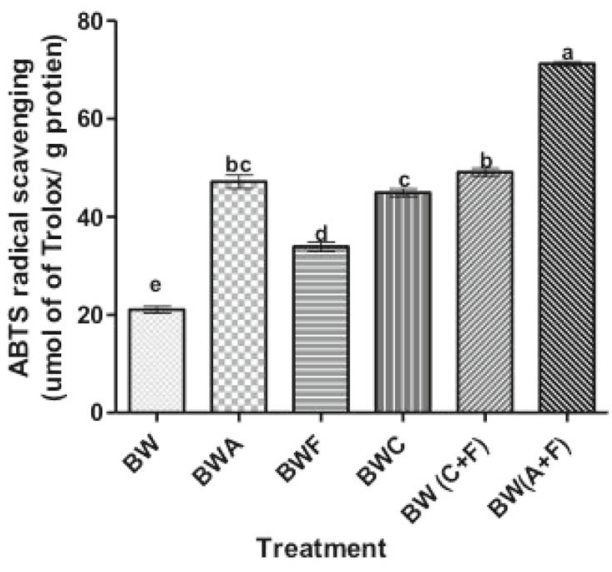

[b]

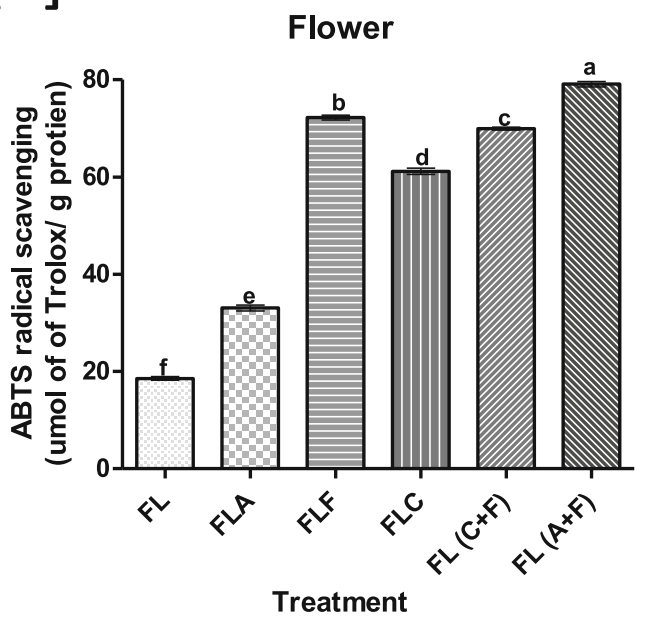

[c]

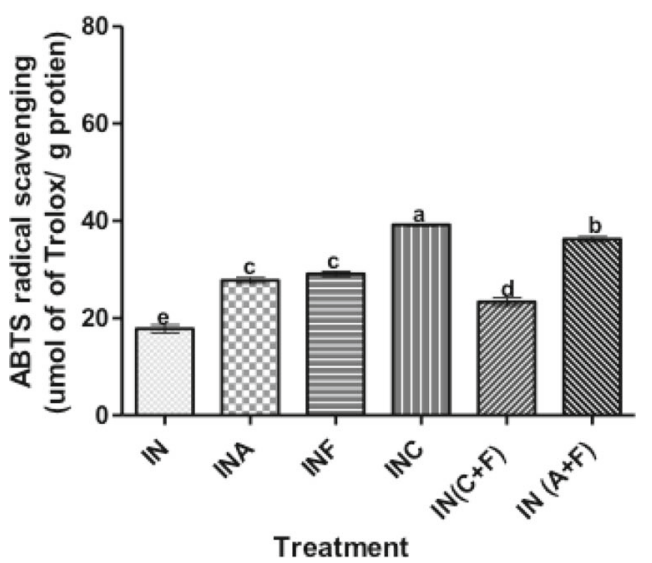

Fig. 5 ABTS radical scavenging activity of sea cucumber $C$. frondosa protein hydrolysates a BW, Body wall; b FL, Flower; and $\mathbf{c} I N$, Internal organs; A, Alcalase; F, Flavourzyme; C, Corolase; C + F, Mixture of Corolase and Flavourzyme; and A + F, Mixture of Alcalase and Flavourzyme. Different letters for the same concentration of all hydrolysates indicates significant difference at $p<0.05$

(Cumby et al. 2008). Hydrolysis patterns of Alcalase, Corolase and Flavourzyme are different due to the fact that Alcalase and Corolase both act as endopeptidases whereas Flavourzyme has both exo- and endopeptidase activities (Kristinsson and Rasco 2000). Therefore, Alcalase and Corolase produce small and medium size peptides. Even though, Alcalase and Corolase have endopeptidase activity, the principal functional group in their active site is different as Alcalase belongs to serine proteases and Corolase is a metalloprotease (Kristinsson and Rasco 2000; Cumby et al. 2008). Moreover, Flavourzyme may produce free amino acids and more low-molecularweight peptides compared to endopeptidase (Hamada 2000). Hence, the varied antioxidant activities among different enzyme treatments may be due to their compositional difference. Therefore, it was presumed that sequential use of Alcalase and Flavourzyme may contribute to the generation of favourable compositional characteristics towards radical scavenging activities compared to other enzymes used in this study.

\section{Metal chelation activity}

In general, peptides can form complexes with transition metal ions and retard the oxidation process (Girgih et al. 2015). This ability is associated with the presence of amino acid residues such as His, Cys, Trp, Asp and Glu that are known to bind divalent metal ions (Udenigwe et al. 2016). In this study, metal chelation ability was ranged from $16.5 \pm 0.90$ to $37.43 \pm 0.98,18.89 \pm 0.55$ to $36.80 \pm 0.59$ and $18.20 \pm 0.17$ to $36.52 \pm 0.59 \mu \mathrm{mol}$ of EDTA equivalents per gram of protein in the hydrolysates prepared from body wall, internal organs and flower, respectively. Chelation of metal ions by sea cucumber protein hydrolysates showed that samples treated with a combination of enzymes (Alcalase+Flavourzyme, Corolase+Flavourzyme) exhibited higher metal chelating ability compared to their untreated counterparts and single enzyme treated samples (Fig. 6).

The lowest metal chelation activity was noted in the untreated samples of each body part. Therefore, similar to radical scavenging abilities (DPPH, ABTS and hydroxyl), metal chelation ability of the protein hydrolysates also varied according to the type of protease used for hydrolysis. Interestingly, we observed that compared to radical scavenging activities of protein hydrolysates prepared from body wall, internal organs and flower 


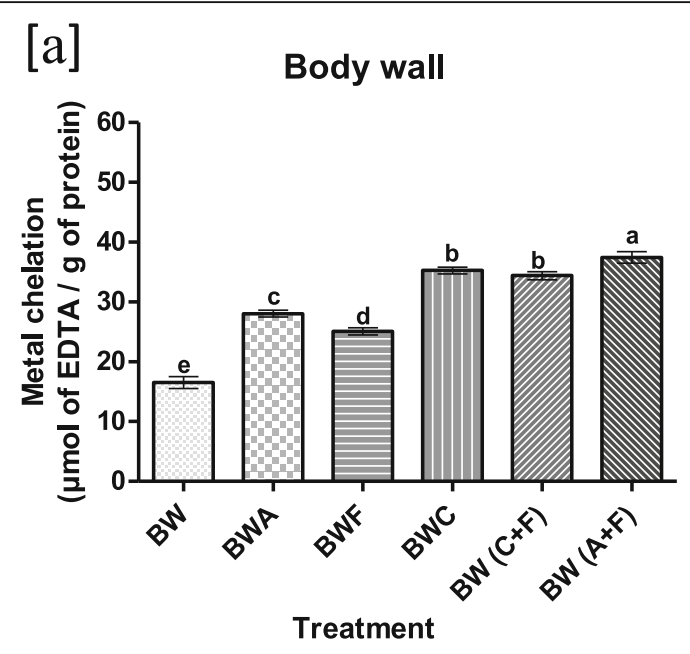

[b]

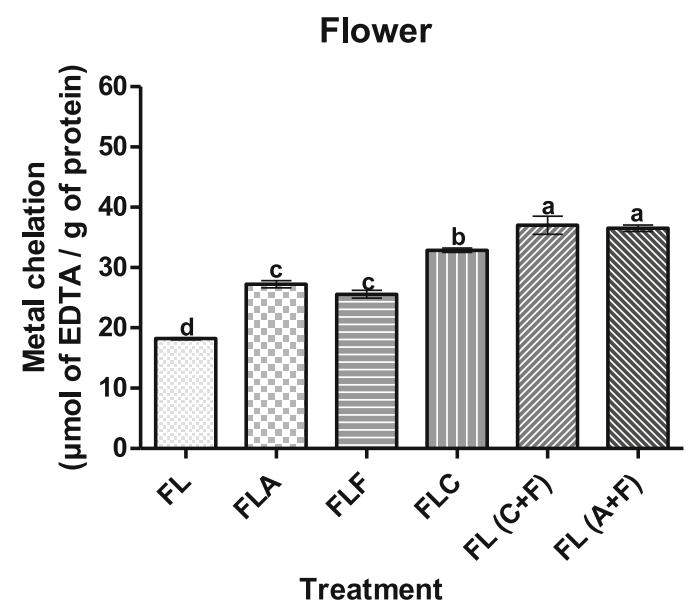

[c]

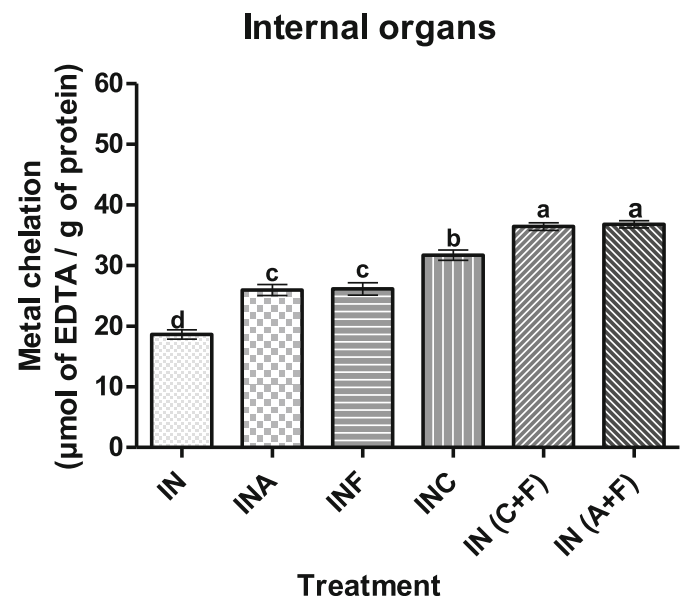

Fig. 6 Metal chelation ability of protein hydrolysates of sea cucumber C. frondosa protein hydrolysates a BW, Body wall; b FL, Flower; and c IN, Internal organs; A, Alcalase; F, Flavourzyme; C, Corolase; C + F, Mixture of Corolase and Flavourzyme; and A + F, Mixture of Alcalase and Flavourzyme. Different letters for the same concentration of all hydrolysates indicates significant difference at $p<0.05$

using Corolase exhibited significantly higher $(p<0.05)$ metal chelation ability than the other single enzyme treatments. This may arise from the fact that the hydrolysis mechanism of the Corolase that belongs to the metalloprotease group of enzymes. Slizyte et al. (2016) stated that larger peptides have better ability to chelate metal ions and their ability weakens with the progression of hydrolysis. As depicted in Fig. 6, metal chelation ability of hydrolysates produced from internal organs showed similar activity compared to those produced from body wall and flower which is different from that in radical scavenging activity assays where internal organ hydrolysates exhibited weaker activity compared to the other two types of hydrolysates. These observations may have an association with protein configuration, amino acid sequence and composition of each protein hydrolysates that are attributed to metal binding abilities. Slizyte et al. (2016) further explained that conflicting results of radical scavenging activities and metal chelation activities of the same hydrolysates can be expected due to the different protein properties related to different antioxidant activity mechanisms.

For instance, the differences observed between the samples may be due to having different charged amino acid side chain residues that have the ability to remove transition metal ions (Ambigaipalan and Shahidi 2017). In addition, presence of histidine at the $\mathrm{N}$ terminal can be attributed to a strong metal ion chelation due its imidazole group. Furthermore, Girgih et al. (2015) stated that unfractionated protein hydrolysates exhibited better metal chelation activity than their fractionated counterparts due to the synergistic effect of the component peptides. However, overall observations of the present study suggest that through an effective use of enzymes sea cucumber hydrolysates may enhance the chelation activity of prooxidant metal ions. Table 1 presents the summary of radical scavenging activities and metal chelating ability of sea cucumber protein hydrolysates.

\section{Antioxidant activity of protein hydrolysates in oil-in water emulsion system}

Thermally induced oxidation of linoleic acid form free radicals and hydroperoxides in the emulsion system by losing a hydrogen atom (Chandrasekara and Shahidi 2010). The free radicals so produced attack $\beta$-carotene, a lipophilic chromophore (yellow-orange colour) and this 
Table 1 In vitro antioxidant activity of sea cucumber protein hydrolysates

\begin{tabular}{|c|c|c|c|}
\hline Sample & $\begin{array}{l}\text { DPPH Radical Scavenging Activity } \\
\text { (mmol of Trolox/g of sample) }\end{array}$ & $\begin{array}{l}\text { ABTS Radical Scavenging Activity } \\
\text { ( } \mu \mathrm{mol} \text { of Trolox/g of sample) }\end{array}$ & $\begin{array}{l}\text { Meta Chelation Activity } \\
\text { ( } \mu \mathrm{mol} \text { of EDTA/g of sample) }\end{array}$ \\
\hline \multicolumn{4}{|l|}{ Body wall } \\
\hline BW & $10.06 \pm 0.80^{d}$ & $21.04 \pm 0.68^{e}$ & $16.55 \pm 1.00^{\mathrm{e}}$ \\
\hline BWA & $12.64 \pm 0.67^{c}$ & $47.13 \pm 1.39^{b c}$ & $28.04 \pm 0.57^{c}$ \\
\hline BWF & $14.29 \pm 0.13^{a b}$ & $33.90 \pm 0.92^{d}$ & $25.09 \pm 0.60^{d}$ \\
\hline BWC & $11.89 \pm 0.41^{c}$ & $44.93 \pm 0.79^{c}$ & $35.26 \pm 0.57^{b}$ \\
\hline $\mathrm{BW}(\mathrm{C}+\mathrm{F})$ & $12.97 \pm 0.20^{b c}$ & $49.13 \pm 0.78^{b}$ & $34.41 \pm 0.68^{b}$ \\
\hline$B W(A+F)$ & $14.66 \pm 0.63^{\mathrm{a}}$ & $71.25 \pm 0.38^{a}$ & $37.44 \pm 0.99^{\mathrm{a}}$ \\
\hline \multicolumn{4}{|l|}{ Flower } \\
\hline $\mathrm{FL}$ & $11.85 \pm 0.83^{d}$ & $18.57 \pm 0.37^{f}$ & $18.20 \pm 0.18^{d}$ \\
\hline FLA & $14.54 \pm 0.33^{c}$ & $33.07 \pm 0.61^{e}$ & $27.21 \pm 0.60^{c}$ \\
\hline FLF & $15.09 \pm 0.76^{b c}$ & $72.21 \pm 0.51^{b}$ & $25.57 \pm 0.65^{c}$ \\
\hline FLC & $15.03 \pm 0.58^{\mathrm{bc}}$ & $61.15 \pm 0.65^{d}$ & $32.88 \pm 0.36^{b}$ \\
\hline $\mathrm{FL}(\mathrm{C}+\mathrm{F})$ & $16.51 \pm 0.18^{\mathrm{ab}}$ & $69.96 \pm 0.30^{c}$ & $37.02 \pm 1.51^{a}$ \\
\hline$F L(A+F)$ & $16.72 \pm 0.29^{a}$ & $79.08 \pm 0.56^{a}$ & $36.53 \pm 0.54^{a}$ \\
\hline \multicolumn{4}{|c|}{ Internal organs } \\
\hline IN & $7.08 \pm 0.42^{c}$ & $17.79 \pm 0.81^{e}$ & $18.66 \pm 0.77^{d}$ \\
\hline INA & $11.83 \pm 0.98^{b}$ & $27.75 \pm 0.58^{c}$ & $25.97 \pm 0.89^{c}$ \\
\hline INF & $12.79 \pm 0.17^{\mathrm{ab}}$ & $29.11 \pm 0.50^{c}$ & $26.16 \pm 1.01^{c}$ \\
\hline INC & $13.03 \pm 0.18^{\mathrm{ab}}$ & $39.15 \pm 0.11^{\mathrm{a}}$ & $31.74 \pm 0.84^{b}$ \\
\hline $\mathbb{I N}(\mathrm{C}+\mathrm{F})$ & $13.20 \pm 0.06^{a}$ & $23.34 \pm 0.82^{d}$ & $36.45 \pm 0.64^{a}$ \\
\hline $\mathbb{I N}(A+F)$ & $13.31 \pm 0.54^{a}$ & $36.21 \pm 0.57^{b}$ & $36.80 \pm 0.60^{a}$ \\
\hline
\end{tabular}

BW Body wall, FL Flower, IN Internal organs, A Alcalase, F Flavourzyme, C Corolase, $C+F$ Mixture of Corolase and Flavourzyme, $A+F$ Mixture of Alcalase and Flavourzyme;

Data are expressed as means \pm SD from triplicate determinations

Different superscripts in each column for the same colour parameter of protein hydrolysates prepared from each body part indicates significant difference at $p<0.05$

leads to decoloration as a result of losing its conjugation. The colour change can be monitored with the time at $470 \mathrm{~nm}$ (Ambigaipalan and Shahidi 2015). $\beta$-carotene is widely used as a coloring agent for food and beverages and its discoloration indicates quality deterioration of the product (Sakanaka et al. 2005). The presence of antioxidants attenuates the rate of discoloration of $\beta$ carotene in the emulsion by scavenging the free radicals (Nasri et al. 2013).

In this study, the enzyme treated samples showed a better inhibition of oxidation compared to their untreated counterparts (Fig. 7). Rapid decoloration of $\beta$-carotene was observed in the control sample compared to all tested samples whereas trolox which was used as standard exhibited the highest inhibitory activity. Overall, among the sea cucumber protein hydrolysates, samples prepared with combination of Alcalase and Flavourzyme showed significantly higher $(p<0.05)$ inhibitory activity against the decoloration of $\beta$-carotene. The observed inhibitory activity of protein hydrolysates and trolox for $120 \mathrm{~min}$ ranged from 56 to $90 \%$, including $88 \%$ in body wall (Alcalase+
Flavourzyme), $86 \%$ in flower (Alcalase+Flavourzyme) and $68 \%$ in internal organs (Alcalase +Flavourzyme) of sea cucumber C.frondosa.

Similar observations were reported for protein hydrolysates prepared from capelin (Amarowicz and Shahidi 1997), date seeds (Ambigaipalan and Shahidi 2015) and shrimp shell discards (Ambigaipalan and Shahidi 2017). Hydrophobic amino acids possess higher efficiency of preventing the oxidation in an oil-in-water emulsion system compared to the hydrophilic residues. This could be due to the orientation of hydrophobic amino acids at the oil-water interface (Ambigaipalan and Shahidi 2017). Especially, hydrophobic amino acids have high affinity for linoleic acid. Therefore, it is presumed that peptides with hydrophobic amino acids could have the ability to scavenge lipid-derived radicals by donating $\mathrm{H}$ atom (Kim et al. 2007). In addition, Kong and Xiong (2006) also reported that short-chain peptides have the ability to disperse at the water-oil interface in a liposome system and then be adsorbed to the phospholipids membrane in the liposome, where oxidation takes place. 


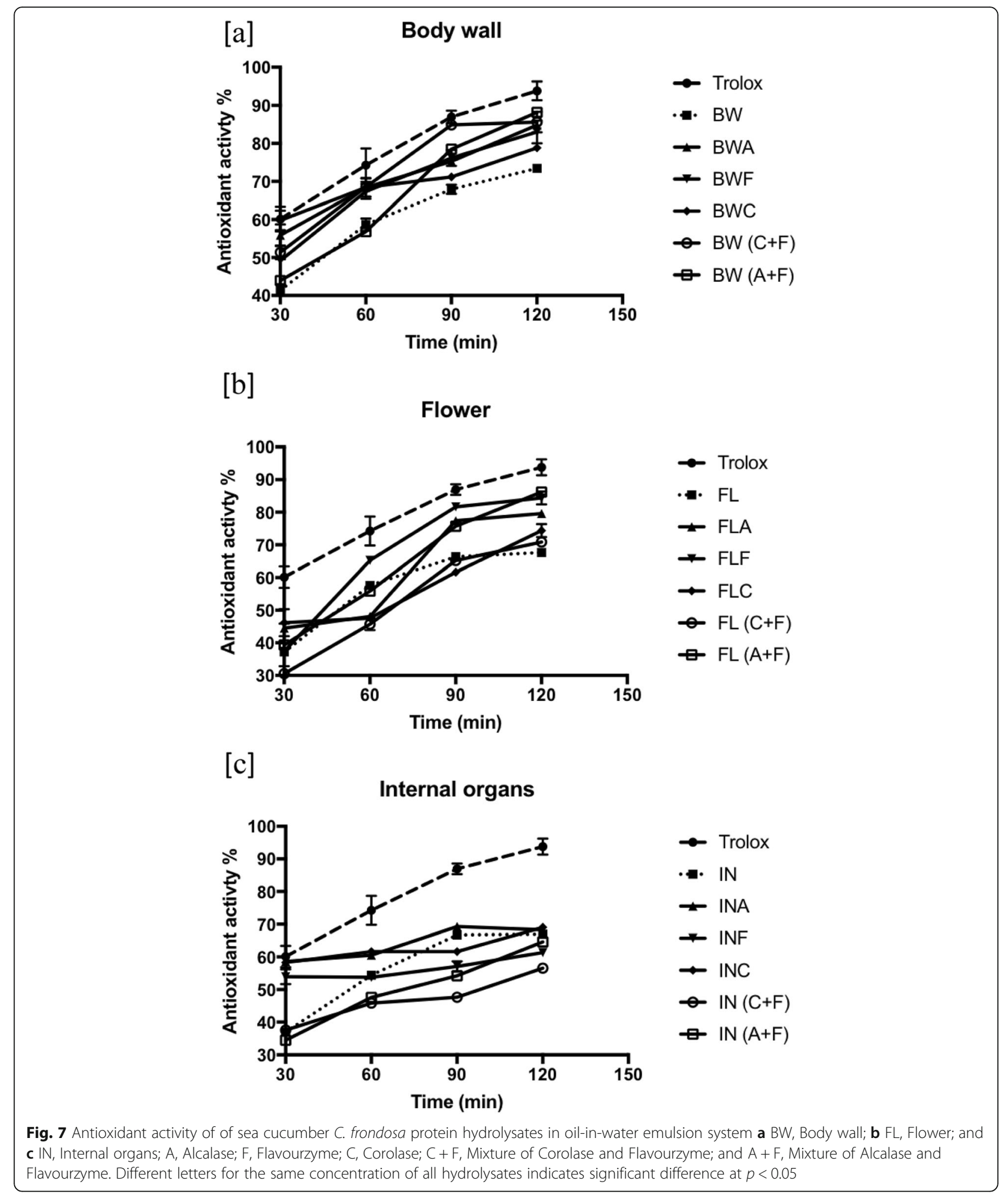

According to Amarowicz and Shahidi (1997), discrepancy in antioxidant activities of peptides might be due to their synergetic action with emulsifier (Tween 40). Moreover, Nasri et al. (2013) have suggested that the $\beta$-carotene decoloration inhibitory activity of protein hydrolysates is influenced by the molecular size of the peptides, its chemical properties and electron transfer ability of its constituent amino acids. 


\section{Antioxidant activity of sea cucumber protein hydrolysates in cooked comminuted meat model system (thiobarbituric acid reactive substances, TBARS)}

The TBA assay is a spectrophotometric detection method to determine the secondary lipid oxidation products that are expressed as MDA (malondialdehyde) equivalents. The secondary oxidative products include aldehydes, alcohols, epoxy compounds and ketones and these are involved in quality deterioration of muscle foods (Shahidi and Zhong 2015). The TBA reagent reacts with the MDA present in the sample and forms MDA-TBA adduct which can be measured at $532 \mathrm{~nm}$ (Shahidi and Synowiecki 1997). Inhibition percentage of TBARS production in meat model systems incorporated with sea cucumber protein hydrolysates displayed a significantly higher $(p<0.05)$ inhibitory activity compared to their untreated counterparts (Fig. 8). Among all samples of each body part of sea cucumber hydrolysed, the combination of Alcalase and Flavourzyme exhibited the highest percentage of inhibition (body wall 25\%, flower $28 \%$, and internal organs $25 \%$ ) followed by hydrolysates prepared with Corolase and Flavourzyme combination (body wall 24\%, flower $22 \%$ and internal organs 13\%) compared to butylated hydroxytoluene (BHT) (29\%) after seven days of storage. Moreover, the same trend was observed in samples treated with a combination of Alcalase and Flavourzyme after 14 days of storage in body wall (35\%) and flower (36\%) compared to BHT (39\%) whereas internal organs $(21 \%)$ showed slight decrease compared to 7 days of storage period. However, the increase in TBARS correlates with production of low-molecular-weight oxidation products with progression of storage time. Further oxidation of short-chain products of lipid oxidation which are unstable may also occur upon prolonged storage. Thus, some of the compounds so formed upon oxidation, such as acids and alcohols, are not determined by the TBA test (Kittiphattanabawon et al. 2012).

These observations are in accordance with inhibition of TBARS production of date seed protein hydrolysates (Ambigaipalan and Shahidi 2015) and egg yolk protein hydrolysates (Sakanaka and Tachibana 2006). The use of single enzyme (individual treatment of exopeptidase or endopeptidase) found to be have lower inhibition of TBARS compared to the combined effect of both type of proteases. These findings indicate that protein hydrolysates prepared from sea cucumber using combination of endopeptidases and exopeptidases could enhance the radical scavenging abilities and metal chelating activity that can have direct impact on TBARS inhibition. Moreover, these findings are in accordance with the radical scavenging activities and metal chelation activities in this study. Hence, both in-vitro chemical assays and model system assays followed a similar trend in evaluating antioxidant potential of sea cucumber protein hydrolysates. Thus, sea cucumber protein hydrolysates prepared using a combination of Alcalase and Flavourzyme as well as Corolase and Flavourzyme might be used as potential natural antioxidants in muscle foods.

\section{Colour measurement of freeze-dried hydrolysates}

Colour is one of the most important intrinsic factors that can influence the consumer acceptability of a food product (Wasswa et al. 2007). Protein hydrolysates of sea cucumber samples were analysed for whiteness (L), redness (a) and yellowness (b). The $\mathrm{L}$ values prepared from body wall were significantly different from their untreated counterparts (Table 2). This trend was observed in the other two samples as highest $\mathrm{L}$ values were obtained for untreated flower and internal organs. The lowest $L$ values and highest $b$ values were shown in hydrolysates prepared using Flavourzyme. During hydrolysis, all sea cucumber samples developed a brownish-yellow colour which was distinct from their untreated counterparts. Similar findings were reported for protein hydrolysates of round scad (Thiansilakul et al. 2007), grass carp (Wasswa et al. 2007), and sliver carp (Dong et al. 2008). This may be due to the oxidation of myoglobin and presence of melanin pigments of the raw material (Thiansilakul et al. 2007). In addition, as the enzymes such as Flavourzyme have a dark colour this may also contribute to the colour of the hydrolysed products. Moreover, it has been suggested that the formation of dark colour during hydrolysis is associated with the Millard browning reaction (Dong et al. 2008). Thus, change in colour of sea cucumber protein hydrolysates is directly influenced by the muscle pigment oxidation and other factors already noted.

\section{Solubility of protein hydrolysates}

Solubility is one of the key parameters influencing other physicochemical and functional properties of protein hydrolysates (Kristinsson and Rasco 2000; Ambigaipalan and Shahidi 2015). The solubility of freeze-dried sea cucumber protein hydrolysates is presented in Figs. 9 a), b) and c) for body wall, flower, and internal organs, respectively. Figure 10 shows the solubility of protein isolates. The solubility of protein isolates showed a typical U-shaped curve, whereas protein hydrolysates exhibited $>75 \%$ of solubility over the $\mathrm{pH}$ range of $2-12$. There was no significant difference between the enzyme treatments of each sample. However, among all treatments, maximum solubility was achieved in the samples treated with Alcalase and Flavourzyme (body wall 94.34\%; flower 90.41\%; internal organs $91.43 \%$ ). In general, solubility improves when $\mathrm{pH}$ shifts toward basic conditions. Similar solubility profiles were observed in protein hydrolysates prepared from Pacific whiting muscle (Pacheco-Aguilar 


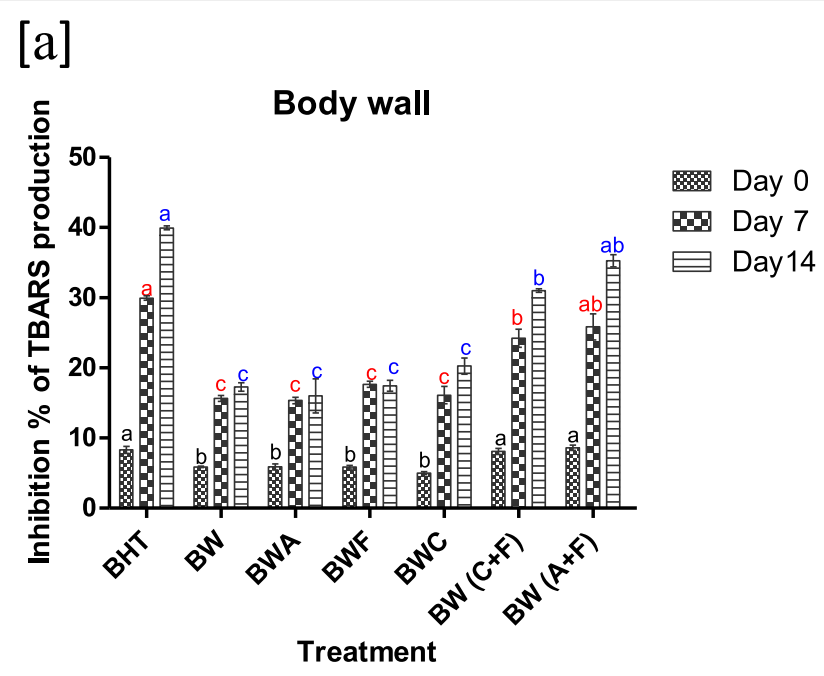

[b]

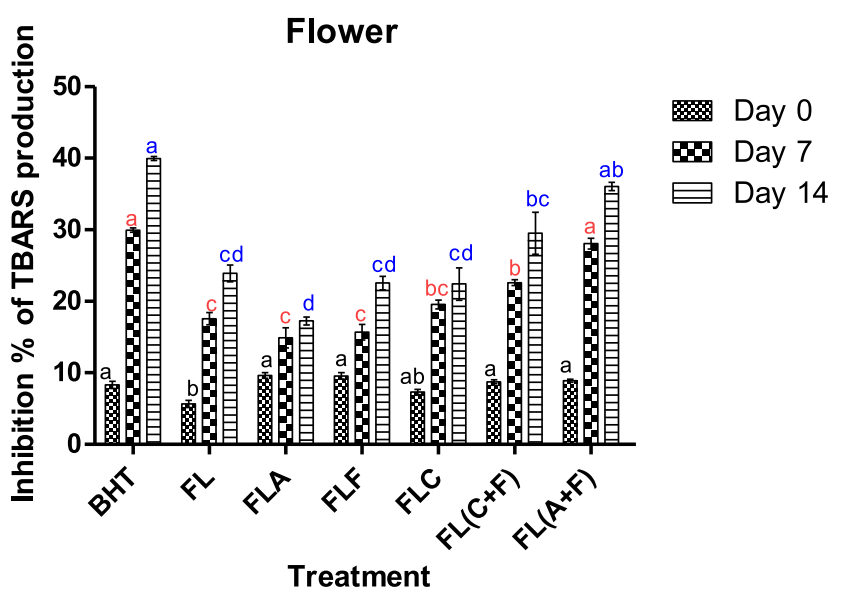

$[c]$

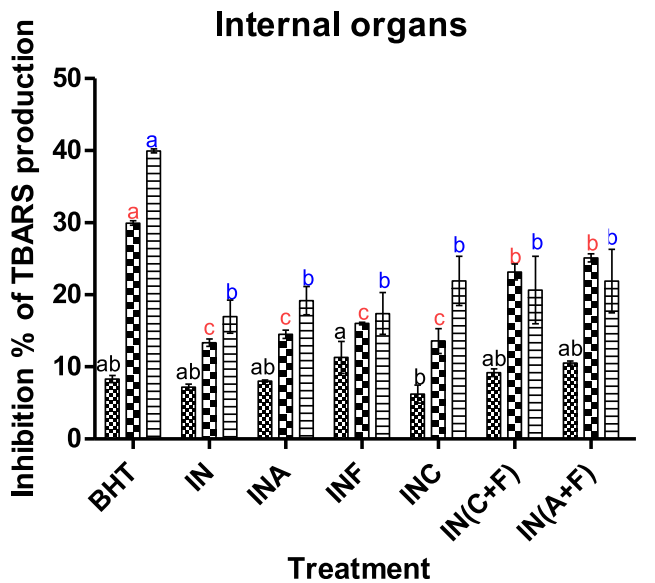

Fig. 8 Inhibition \% of TBARS production of protein hydrolysates of sea cucumber C. frondosa protein hydrolysates a BW, Body wall; b FL, Flower; and $\mathbf{c} I N$, Internal organs; A, Alcalase; F, Flavourzyme; C, Corolase; C + F, Mixture of Corolase and Flavourzyme; and A + F, Mixture of Alcalase and Flavourzyme. Different letters for the same concentration of all hydrolysates indicates significant difference at $p<0.05$ 
Table 2 The colour of sea cucumber C. frondosa protein hydrolysates

\begin{tabular}{|c|c|c|c|}
\hline Sample & $\mathrm{L}$ & $a$ & b \\
\hline \multicolumn{4}{|l|}{ Body wall } \\
\hline BW & $57.92 \pm 0.35^{a}$ & $2.79 \pm 0.55^{b}$ & $17.05 \pm 0.19^{\mathrm{a}}$ \\
\hline BWA & $55.60 \pm 0.72^{b}$ & $3.86 \pm 0.58^{\mathrm{a}}$ & $18.03 \pm 0.88^{a}$ \\
\hline BWF & $50.59 \pm 0.22^{d}$ & $2.70 \pm 0.09^{b}$ & $17.32 \pm 0.87^{\mathrm{a}}$ \\
\hline BWC & $54.33 \pm 0.69^{b}$ & $2.67 \pm 0.44^{b}$ & $17.74 \pm 0.57^{\mathrm{a}}$ \\
\hline$B W(C+F)$ & $52.62 \pm 0.05^{c}$ & $2.91 \pm 0.24^{b}$ & $18.14 \pm 0.96^{\mathrm{a}}$ \\
\hline$B W(A+F)$ & $56.68 \pm 0.47^{a}$ & $3.89 \pm 0.46^{a}$ & $18.13 \pm 0.78^{a}$ \\
\hline \multicolumn{4}{|l|}{ Flower } \\
\hline $\mathrm{FL}$ & $43.66 \pm 0.30^{a}$ & $2.92 \pm 0.11^{b}$ & $17.06 \pm 0.05^{c}$ \\
\hline FLA & $42.88 \pm 0.15^{b}$ & $3.92 \pm 0.32^{\mathrm{a}}$ & $18.11 \pm 0.62^{b}$ \\
\hline FLF & $41.26 \pm 0.40^{b}$ & $3.25 \pm 0.15^{b}$ & $18.91 \pm 0.11^{\mathrm{a}}$ \\
\hline $\mathrm{FLC}$ & $42.11 \pm 0.04^{b}$ & $3.87 \pm 0.10^{\mathrm{a}}$ & $17.03 \pm 0.10^{c}$ \\
\hline $\mathrm{FL}(\mathrm{C}+\mathrm{F})$ & $42.46 \pm 0.26^{b}$ & $2.34 \pm 0.04^{c}$ & $18.99 \pm 0.07^{b}$ \\
\hline$F L(A+F)$ & $41.97 \pm 0.28^{b}$ & $3.31 \pm 0.33^{b}$ & $18.00 \pm 0.29^{a}$ \\
\hline \multicolumn{4}{|c|}{ Internal organs } \\
\hline IN & $41.89 \pm 0.78^{\mathrm{a}}$ & $2.92 \pm 0.05^{\mathrm{b}}$ & $17.01 \pm 0.21^{b}$ \\
\hline INA & $43.25 \pm 0.35^{a}$ & $2.14 \pm 0.56^{c}$ & $18.18 \pm 1.21^{\mathrm{a}}$ \\
\hline INF & $43.13 \pm 0.39^{a}$ & $3.35 \pm 0.26^{a}$ & $18.05 \pm 0.11^{\mathrm{a}}$ \\
\hline INC & $42.34 \pm 0.32^{a}$ & $3.65 \pm 0.57^{\mathrm{a}}$ & $17.58 \pm 1.23^{\mathrm{a}}$ \\
\hline $\mathbb{I N}(C+F)$ & $43.00 \pm 0.33^{a}$ & $3.21 \pm 0.70^{a}$ & $18.80 \pm 0.89^{\mathrm{a}}$ \\
\hline $\mathbb{I N}(A+F)$ & $43.49 \pm 0.67^{a}$ & $3.26 \pm 0.45^{\mathrm{a}}$ & $17.11 \pm 0.46^{\mathrm{a}}$ \\
\hline
\end{tabular}

L, whiteness; a, redness; b, yellowness; $B W$ Body wall, FL Flower, IN Internal organs, A Alcalase, $F$ Flavourzyme, $C$ Corolase, $C+F$ Mixture of Corolase and Flavourzyme, $A+F$ Mixture of Alcalase and Flavourzyme;

Data are expressed as means \pm SD from triplicate determinations

Different superscripts in each column for the same colour parameter of protein hydrolysates prepared from each body part indicates significant difference at $p<0.05$ et al. 2008), echinoderm by-products (Mamelona et al. 2010b), skipjack roe (Intarasirisawat et al. 2012), cricket (Hall et al. 2017) and starry triggerfish muscle (Sripokar et al. 2019). Change of net charge of the amino acid residues due to alteration of $\mathrm{pH}$ and generation of lowmolecular-weight peptides during hydrolysis are identified as major factors promoting the solubility of protein hydrolysates over a wide range of $\mathrm{pH}$ (Ambigaipalan and Shahidi 2015; Sripokar et al. 2019). The enzymatic hydrolysis changes the hydrophobicity of the protein hydrolysates by affecting the balance of hydrophilic and hydrophobic groups of the peptides as well as releasing of polar and ionizable groups (Intarasirisawat et al. 2012). Findings of the present study suggest that protein hydrolysates produced from sea cucumber exhibit better solubility over a wide range of $\mathrm{pH}$ compared to their unhydrolyzed counterparts. These results demonstrate the potential of using sea cucumber protein hydrolysates in a wide variety of food systems including emulsions, gels, and foams.

\section{Determination of water holding capacity (WHC) of protein hydrolysates using a meat model system}

Water holding capacity is a key attribute for the texture properties of food products (Wouters et al. 2016). All sea cucumber protein hydrolysates enhanced the WHC of the meat compared with untreated counterpart samples (Fig. 11). Improved WHC correlates with the cooking yield of the meat (Cumby et al. 2008). With respect to the cooking yield, most effective samples were sea cucumber body parts treated with a combination of Alcalase and Flavourzyme and the least effective was unhydrolyzed samples of sea cucumber body parts. These findings are in agreement with those of capelin hydrolysates (Shahidi et al. 1995), rapeseed protein hydrolysates (Cumby et al. 2008) and date seed protein hydrolysates (Ambigaipalan and Shahidi 2015).

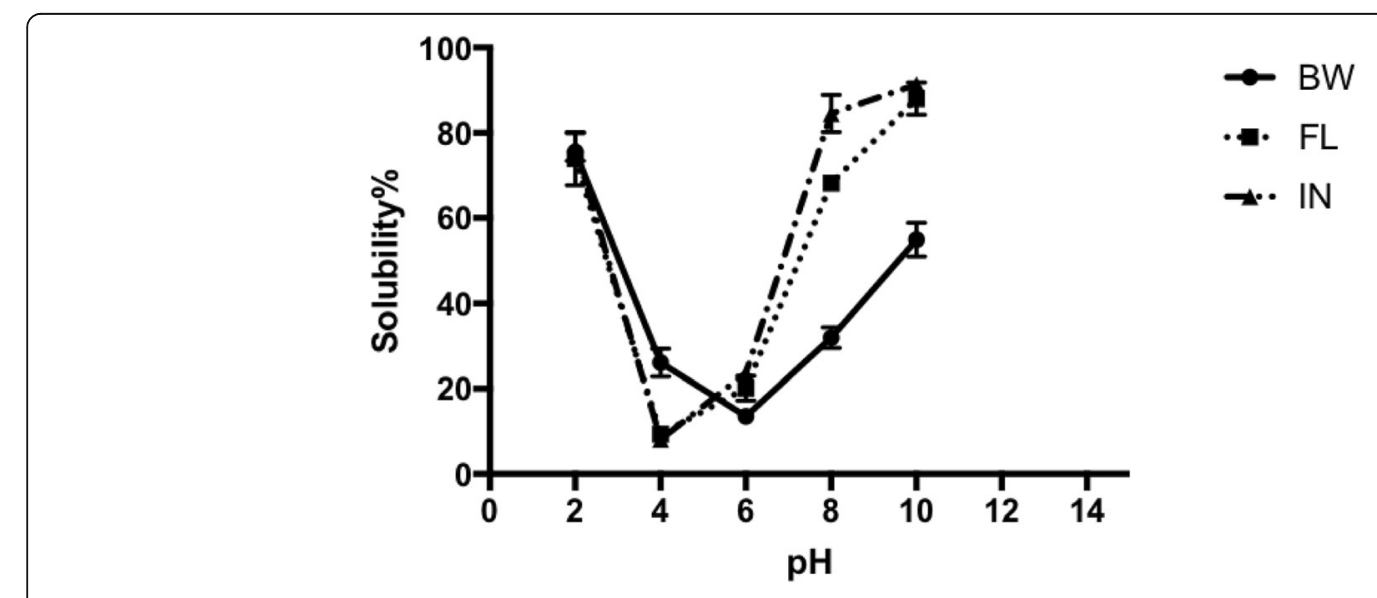

Fig. 9 Solubility of untreated sea cucumber C. frondosa proteins at various pH values BW, Body wall; FL, Flower; and IN, Internal organs 


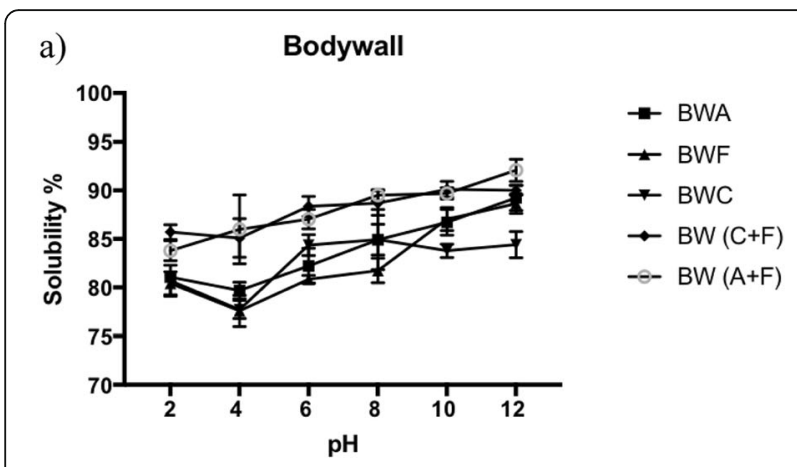

b) Flower
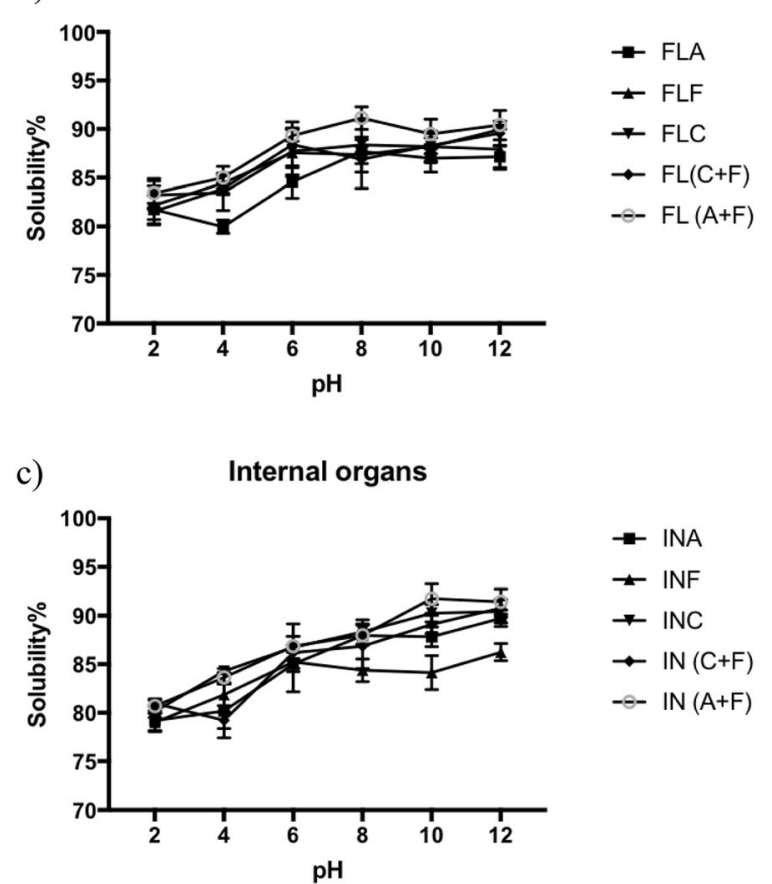

Fig. 10 Solubility of sea cucumber $C$. frondosa protein hydrolysates at various $\mathrm{pH}$ values a BW, Body wall; b FL, Flower; c IN, Internal organs A, Alcalase; F, Flavourzyme; C, Corolase; C + F, Mixture of Corolase and Flavourzyme; $A+F$, Mixture of Alcalase and Flavourzyme

According to Cumby et al. (2008), water holding capacity of food protein hydrolysates depends on the type of protease used for enzymatic hydrolysis, proteolysis condition and availability of low-molecular-weight peptides. In particular, low-molecular-weight peptide fragments promote the WHC of the protein hydrolysates by decreasing the dripping volume. This may be associated with the greater hydrophilic nature of the lowmolecular-weight peptides compared to larger size peptides or unhydrolyzed proteins (Cumby et al. 2008; Ambigaipalan and Shahidi 2015). In addition, the presence of polar amino acid residues also contributes to the improved WHC of protein hydrolysates. Cumby et al. (2008) suggested that the use of Flavourzyme promotes the cooking yield of the meat products by preserving the amino acid residues of the protein hydrolysates and this was better than those prepared with Alcalase and Colorase. Based on our findings reported here, sea cucumber protein hydrolysates could be utilized as a natural alternative to sodium tripolyphosphate (STPP) to enhance the cooking yield of meat or other muscle food products, as shown in Fig. 9.

\section{Amino acid composition of protein hydrolysates}

Amino acid composition plays a vital role in bioactivities and physiochemical properties of protein hydrolysates. Protein hydrolysates digested with Alcalase and Flavourzyme were further analysed for their total amino acid profiles. As shown in Table 3, glutamic acid was dominant in all three samples, followed by glycine in both body wall and flower and arginine in internal organs. These findings are consistent with the published amino acid composition for Cucumaria frondosa by Zhong et al. (2007), Mamelona et al. (2010b), and Yan et al. (2016). The non-essential amino acid composition (NEAA) of the present study also corresponds with the previous studies on different sea cucumber species including Parastichopus tremulus and Holothuria forskali (García et al. 2019) and Holothuria arguinensis (Roggatz et al. 2016).

Leucine was the most abundant essential amino acid (EAA) found in body wall and flower samples, whereas the essential amino acid with the highest concentration in internal organ sample was lysine. Tryptophan, histidine and methionine showed a relatively low amount in all three samples. Similar findings were reported in protein hydrolysates produced using Alcalase and trypsin from whole sea cucumber (Zhang et al. 2020). Shahidi et al. (1995) stated that sensitive amino acids, including methionine and tryptophan, may be largely affected during the analysis process.

However, in terms of nutritional value, all three samples were rich in essential amino acids (30-40\%). The highest ratio EAA/NEAA was shown in internal organ hydrolysates (0.66), followed by flower (0.48) and body wall (0.47). These calculated ratios well coincide with the findings of Zhong et al. (2007) that the ratio was higher in Cucumaria frondosa with internal organs (0.59) compared to the samples devoid of internal organs $(0.45,0.47)$. Moreover, a similar ratio was reported for sea cucumber guts of Stichopus japonicus (0.65) (Du et al. 2019). The ratio EAA /NEAA is considered as an indicator for protein quality of different dietary protein sources (Shahidi 1994).

As indicated in Table 3, amino acid profiles of sea cucumber protein hydrolysates fulfill the recommendations of the World Health Organization /Food and Agriculture Organization (WHO/FAO) 1991 for the amount of 
a)

\section{Body wall}

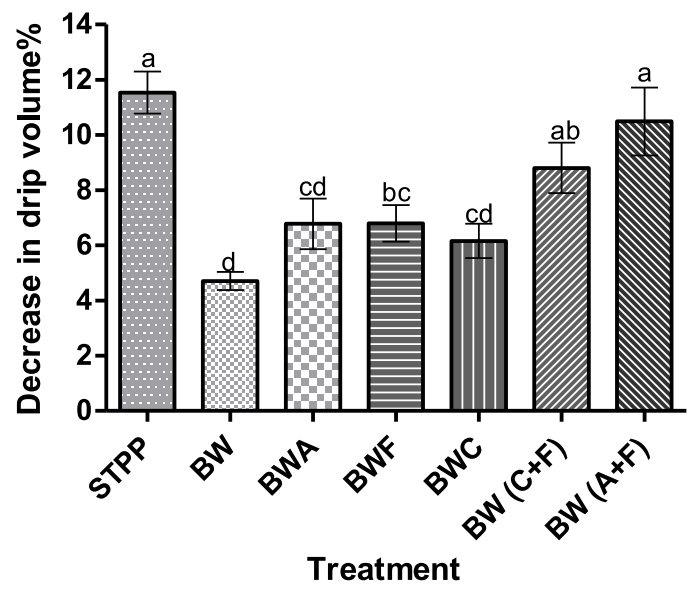

b)

Flower

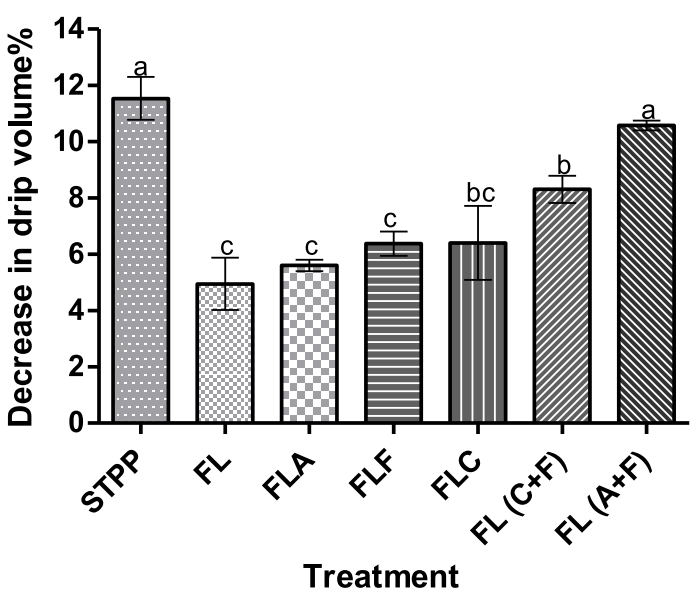

c)

Internal Organs

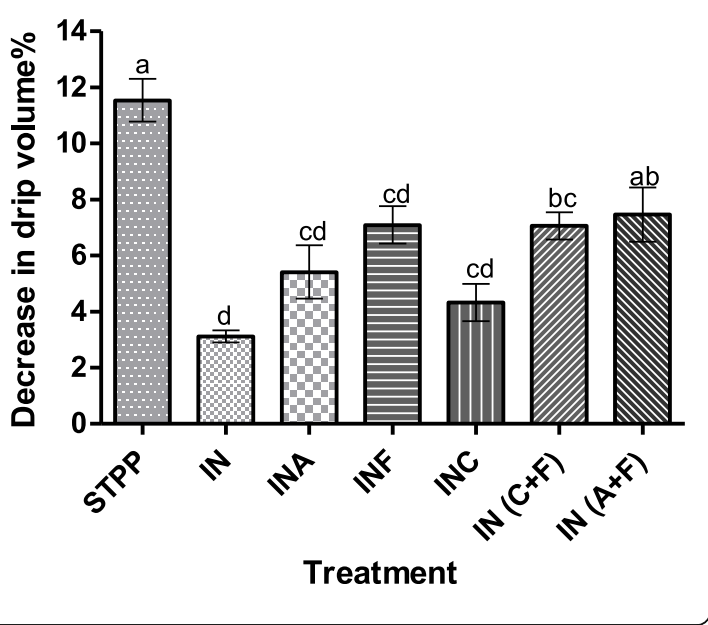

Fig. 11 Decrease in drip volume of sea cucumber $C$. frondosa protein hydrolysates a BW, Body wall; b FL, Flower; and c IN, Internal organs; A, Alcalase; F, Flavourzyme; C, Corolase; C + F, Mixture of Corolase and Flavourzyme; and A +F, Mixture of Alcalase and Flavourzyme. Different letters for the same concentration of all hydrolysates indicates significant difference at $p<0.05$

most of essential amino acids in food products. The results demonstrate that sea cucumber protein hydrolysates can be used as a source of balanced dietary proteins (Table 4). All three samples showed similar values in terms of their contents of total hydrophobic amino acids and total aromatic amino acids. Hydrophobic amino acids contribute to the antioxidant and ACE inhibitory activities of the protein hydrolysates (Udenigwe et al. 2016; Ambigaipalan and Shahidi 2017). Zhang et al. (2020) identified tyrosine, methionine, histidine, cysteine and tryptophan as key antioxidative amino acids present in sea cucumber protein hydrolysates. For example, tyrosine residue could serve as a potent hydrogen donor and histidine can be attributed to the metal chelation and lipid radical-trapping ability of the imidazole ring (Thiansilakul et al. 2007).

In addition, findings of Yan et al. (2016) indicated that amino acid residues, including aspartic and glutamic acids, were also responsible for the antioxidant activities displayed by sea cucumber gut Stichopus japonicus protein hydrolysates. Negatively charged aspartic and glutamic acids possess excess electrons that can easily be donated and act as free radical scavengers (Nwachukwu and Aluko 2019). Furthermore, most of the abundant amino acids in sea cucumber protein hydrolysates are crucial in important physiological functions. For example, glutamine is considered as conditionally essential in catabolic states (Mamelona et al. 2010b) while leucine, isoleucine and valine are important in regulating blood sugar levels and enhancing physical and mental wellbeing by affecting fatigue conditions (Zhang et al. 2020). Moreover, glycine and low ratios of lysine to arginine have a significant impact on the reduction of serum cholesterol profiles that are directly associated with cardiovascular conditions (Pérez-Vega et al. 2013). The ratio of lysine to arginine for body wall, flower and internal organs were $0.49,0.52$ and 0.78 , respectively. These findings imply that amino acid composition could be one of the determinant factors for most of the biological activities exerted by protein hydrolysates of $\mathrm{Cucu}$ maria frondosa prepared from the sequential addition of Alcalase and Flavourzyme.

\section{Conclusion}

This study demonstrated the antioxidative function and beneficial physicochemical properties of protein hydrolysates from different tissues of sea cucumber. According 
Table 3 Amino acid composition of protein hydrolysates (Alcalase+Flavourzyme) from different body parts of the North Atlantic sea cucumber (Mole \%)

\begin{tabular}{|c|c|c|c|}
\hline \multirow[t]{2}{*}{ Name } & \multicolumn{3}{|c|}{ Hydrolysates } \\
\hline & Body wall & Flower & Internal organs \\
\hline \multicolumn{4}{|l|}{ Essential AA (EAA) } \\
\hline Histidine (His) & 1.56 & 1.70 & 2.06 \\
\hline Isoleucine (Ile) & 3.59 & 3.58 & 4.27 \\
\hline Leucine (Leu) & 5.37 & 5.38 & 6.45 \\
\hline Lysine (Lys) & 4.77 & 5.13 & 7.74 \\
\hline Methionine (Met) & 1.85 & 1.71 & 2.36 \\
\hline Phenylalanine (Phe) & 3.91 & 3.95 & 4.37 \\
\hline Threonine (Thr) & 5.18 & 5.30 & 5.84 \\
\hline Tryptophan (Trp) & 1.06 & 1.10 & 1.49 \\
\hline Valine (Val) & 4.54 & 4.71 & 5.35 \\
\hline Total EAA & 31.84 & 32.56 & 39.93 \\
\hline \multicolumn{4}{|l|}{ Non EAA (NEEA) } \\
\hline Alanine (Ala) & 5.88 & 5.72 & 4.93 \\
\hline Arginine (Arg) & 9.71 & 9.90 & 9.90 \\
\hline Aspartic acid +Asparagine (Asp+Asn) & 9.53 & 9.56 & 9.16 \\
\hline Cystine (Cys) & 1.33 & 1.55 & 1.79 \\
\hline Glutamic acid +Glutamine (Glu + Gln) & 14.61 & 14.50 & 14.06 \\
\hline Glycine (Gly) & 11.14 & 10.56 & 5.82 \\
\hline Proline (Pro) & 6.18 & 5.90 & 4.27 \\
\hline Serine (Ser) & 6.09 & 5.98 & 5.60 \\
\hline Tyrosine (Tyr) & 3.68 & 3.77 & 4.53 \\
\hline Total NEAA & 68.16 & 67.44 & 60.07 \\
\hline EAA/ NEAA & 0.47 & 0.48 & 0.66 \\
\hline Total polar AA & 56.47 & 57.39 & 60.68 \\
\hline Total hydrophobic AA & 43.53 & 42.61 & 39.32 \\
\hline Total Aromatic AA & 7.59 & 7.72 & 8.91 \\
\hline Branched chain AA & 13.50 & 13.67 & 16.07 \\
\hline
\end{tabular}

Table 4 Comparison of essential amino acid composition of protein hydrolysates from different body parts of the North Atlantic sea cucumber and World Health Organization /Food and Agriculture Organization (WHO/FAO) recommendations ( $\mathrm{g} / 100 \mathrm{~g}$ )

\begin{tabular}{|c|c|c|c|c|}
\hline \multirow[t]{2}{*}{ Amino Acid } & \multirow{2}{*}{$\begin{array}{l}\text { WHO/ } \\
\text { FAO }\end{array}$} & \multicolumn{3}{|c|}{ Hydrolysates } \\
\hline & & Body wall & Flower & Internal organs \\
\hline Histidine (His) & 1.60 & 0.75 & 0.87 & 0.79 \\
\hline Threonine (Thr) & 0.90 & 2.50 & 2.73 & 2.22 \\
\hline Valine (Val) & 1.30 & 2.19 & 2.42 & 2.04 \\
\hline Methionine (Met) & 1.70 & 0.89 & 0.88 & 0.90 \\
\hline Isoleucine (lle) & 1.30 & 1.73 & 1.85 & 1.63 \\
\hline Leucine (Leu) & 1.90 & 2.59 & 2.77 & 2.46 \\
\hline Phenylalanine+ Tyrosine (Phe + Tyr) & 1.90 & 5.85 & 6.40 & 5.434 \\
\hline Lysine (Lys) & 1.60 & 2.30 & 2.64 & 2.95 \\
\hline Tryptophan (Trp) & 0.50 & 0.51 & 0.57 & 0.57 \\
\hline
\end{tabular}


to the findings, a significant difference existed in antioxidant activities between enzyme treatments which was attributed to the efficacy difference of proteases used in the current study. Subsequent use of endo- and exopeptidases provide better protective functions over oxidation in food systems than employing individual enzymes. Consequently, it was also revealed that despite the proteases used for hydrolysis, all treatments showed higher antioxidant capacity compared to their unhydrolysed protein counterparts. This indicates that use of enzyme technology would be an effective strategy to enhance the bioactive properties as well as the functionalities of sea cucumber proteins. Enzyme hydrolysis has a positive impact on upgrading sea cucumber processing discards to functional food and nutraceutical ingredients. Therefore, hydrolysates prepared from different sea cucumber tissues, specifically the processing by-products may potentially be used as a natural value-added ingredient with antioxidative properties and functionalities. In addition, sea cucumber protein hydrolysates may potentially serve as a good source of dietary protein due to their rich profile of essential amino acids. However, further investigations are needed to characterize the specific peptides and their amino acid sequences responsible for antioxidant and other biological activities.

\section{Abbreviations}

BW: Body wall; FL: Flower; IN: Internal organs; A: Alcalase; F: Flavourzyme; C: Corolase; C + F: Mixture of Corolase and Flavourzyme; A + F: Mixture of Alcalase and Flavourzyme; TNBS: Trinitrobenzenesulfonic acid acid; DPPH: 2,2diphenyl-1,1-picrylhydrazyl; ABTS: 2,2'-azinobis (3-ethylbenzothiazoline-6sulfonate); TBARS: Thiobarbituric acid reactive substances; WHC: Water holding capacity

\section{Acknowledgments}

The authors wish to thank SPARC BioCentre (Molecular Analysis), The Hospital for Sick Children, Toronto, Canada for assistance with amino acid analysis.

\section{Authors' contributions}

T.S. performed the experiments, data curation, writing the initial draft and visualization. D.D. and F.S., conceptualization, supervision and review and edited the manuscript. All authors read and approved the final manuscript.

\section{Funding}

The research was supported by the Natural Sciences and Engineering Research Council (NSERC) of Canada, RGPIN-2015-06121.

\section{Availability of data and materials}

All needed data is presented in this manuscript.

\section{Ethics approval and consent to participate}

Not applicable.

\section{Consent for publication}

All authors consent to the publication of the manuscript.

\section{Competing interests}

The authors declare no conflict of interest.

\section{Author details}

${ }^{1}$ Department of Biochemistry, Memorial University of Newfoundland, St John's, NL A1B 3X9, Canada. ${ }^{2}$ Marine Bioprocessing Facility, Centre of
Aquaculture and Seafood Development, Fisheries and Marine Institute, Memorial University of Newfoundland, St. John's, NL A1C 5R3, Canada.

Received: 1 October 2020 Accepted: 16 December 2020

Published online: 01 February 2021

\section{References}

Adler-Nissen, J. (1979). Determination of the degree of hydrolysis of food protein hydrolysates by trinitrobenzenesulfonic acid. Journal of Agricultural and Food Chemistry, 27(6), 1256-1262.

Amarowicz, R., \& Shahidi, F. (1997). Antioxidant activity of peptide fractions of capelin protein hydrolysates. Food Chemistry, 58(4), 355-359.

Ambigaipalan, P., Al-Khalifa, A. S., \& Shahidi, F. (2015). Antioxidant and angiotensin I converting enzyme (ACE) inhibitory activities of date seed protein hydrolysates prepared using Alcalase, Flavourzyme and Thermolysin. Journal of Functional Foods, 18, 1125-1137.

Ambigaipalan, P., \& Shahidi, F. (2015). Antioxidant potential of date (Phoenix dactylifera L.) seed protein hydrolysates and carnosine in food and biological systems. Journal of Agricultural and Food Chemistry, 63(3), 864-871.

Ambigaipalan, P., \& Shahidi, F. (2017). Bioactive peptides from shrimp shell processing discards: Antioxidant and biological activities. Journal of Functional Foods, 34, 7-17.

Ben Khaled, H., Ktari, N., Ghorbel-Bellaaj, O., Jridi, M., Lassoued, I., \& Nasri, M. (2014). Composition, functional properties and in vitro antioxidant activity of protein hydrolysates prepared from sardinelle (Sardinella aurita) muscle. Journal of Food Science and Technology, 51(4), 622-633.

Chandrasekara, A., \& Shahidi, F. (2010). Content of insoluble bound phenolics in millets and their contribution to antioxidant capacity. Journal of Agricultural and Food Chemistry, 58(11), 6706-6714.

Chandrasekara, A., \& Shahidi, F. (2011). Determination of antioxidant activity in free and hydrolyzed fractions of millet grains and characterization of their phenolic profiles by HPLC-DAD-ESI-MSn. Journal of Functional Foods, 3(3), 144-158.

Cumby, N., Zhong, Y., Naczk, M., \& Shahidi, F. (2008). Antioxidant activity and water-holding capacity of canola protein hydrolysates. Food Chemistry, 109(1), 144-148.

Dong, S., Zeng, M., Wang, D., Liu, Z., Zhao, Y., \& Yang, H. (2008). Antioxidant and biochemical properties of protein hydrolysates prepared from silver carp (Hypophthalmichthys molitrix). Food Chemistry, 107(4), 1485-1493.

Du, Y. N., Guo, X. K., Han, Y. T., Han, J. R., Yan, J. N., Shang, W. H., \& Wu, H. T. (2019). Physicochemical and functional properties of protein isolate from sea cucumber (Stichopus japonicus) guts. Journal of Food Processing and Preservation, 43(7), 1-11.

García, J., Méndez, D., Álvarez, M., Sanmartin, B., Vázquez, R., Regueiro, L., \& Atanassova, M. (2019). Design of novel functional food products enriched with bioactive extracts from holothurians for meeting the nutritional needs of the elderly. LWT- Food Science and Technology, 109, 55-62.

García-Moreno, P. J., Batista, I., Pires, C., Bandarra, N. M., Espejo-Carpio, F. J., Guadix, A., \& Guadix, E. M. (2014). Antioxidant activity of protein hydrolysates obtained from discarded Mediterranean fish species. Food Research International, 65, 469-476.

Girgih, A. T., He, R., Hasan, F. M., Udenigwe, C. C., Gill, T. A., \& Aluko, R. E. (2015). Evaluation of the in vitro antioxidant properties of a cod (Gadus morhua) protein hydrolysate and peptide fractions. Food Chemistry, 173, 652-659.

Girgih, A. T., Udenigwe, C. C., \& Aluko, R. E. (2011). In vitro antioxidant properties of hemp seed (Cannabis sativa L.) protein hydrolysate fractions. JAOCS, Journal of the American Oil Chemists' Society, 88(3), 381-389.

Girgih, A. T., Udenigwe, C. C., Hasan, F. M., Gill, T. A., \& Aluko, R. E. (2013). Antioxidant properties of Salmon (Salmo salar) protein hydrolysate and peptide fractions isolated by reverse-phase HPLC. Food Research International, 52, 315-322.

Hall, F. G., Jones, O. G., O'Haire, M. E., \& Liceaga, A. M. (2017). Functional properties of tropical banded cricket (Gryllodes sigillatus) protein hydrolysates. Food Chemistry, 224, 414-422.

Hamada, J. S. (2000). Characterization and functional properties of rice bran proteins modified by commercial exoproteases and endoproteases. Journal of Food Science, 65(2), 305-310.

He, S., Wang, F., Ning, Z., Yang, B., \& Wang, Y. (2014). Preparation of anchovy (Engraulis japonicus) protein hydrolysates with high free radical-scavenging activity using endogenous and commercial enzymes. Food Science and Technology International, 20(8), 567-578. 
Hossain, A., Dave, D., \& Shahidi, F. (2020). Northern Sea cucumber (Cucumaria frondosa): A potential candidate for functional food, nutraceutical, and pharmaceutical sector. Marine Drugs, 18(5), 274.

Intarasirisawat, R., Benjakul, S., Visessanguan, W., \& Wu, J. (2012). Antioxidative and functional properties of protein hydrolysate from defatted skipjack (Katsuwonous pelamis) roe. Food Chemistry, 135(4), 3039-3048.

John, J. A., \& Shahidi, F. (2010). Phenolic compounds and antioxidant activity of Brazil nut (Bertholletia excelsa). Journal of Functional Foods, 2(3), 196-209.

Khantaphant, S., \& Benjakul, S. (2008). Comparative study on the proteases from fish pyloric caeca and the use for production of gelatin hydrolysate with antioxidative activity. Comparative Biochemistry and Physiology. Part B, Biochemistry \& Molecular Biology, 151(4), 410-419.

Kim, S. Y., Je, J. Y., \& Kim, S. K. (2007). Purification and characterization of antioxidant peptide from hoki (Johnius belengerii) frame protein by gastrointestinal digestion. The Journal of Nutritional Biochemistry, 18(1), 31-38,

Kittiphattanabawon, P., Benjakul, S., Visessanguan, W., \& Shahidi, F. (2012). Gelatin hydrolysate from blacktip shark skin prepared using papaya latex enzyme: Antioxidant activity and its potential in model systems. Food Chemistry, 135(3), 1118-1126.

Klompong, V., Benjakul, S., Kantachote, D., Hayes, K. D., \& Shahidi, F. (2008). Comparative study on antioxidative activity of yellow stripe trevally protein hydrolysate produced from Alcalase and Flavourzyme. International Journal of Food Science and Technology, 43(6), 1019-1026.

Kong, B., \& Xiong, Y. L. (2006). Antioxidant activity of zein hydrolysates in a liposome system and the possible mode of action. Journal of Agricultural and Food Chemistry, 54(16), 6059-6068.

Kristinsson, H. G., \& Rasco, B. A. (2000). Fish protein hydrolysates: Production, biochemical, and functional properties. Critical Reviews in Food Science and Nutrition, 40(1), 43-81.

Ktari, N., Jridi, M., Bkhairia, I., Sayari, N., Ben Salah, R., \& Nasri, M. (2012). Functionalities and antioxidant properties of protein hydrolysates from muscle of zebra blenny (Salaria basilisca) obtained with different crude protease extracts. Food Research International, 49(2), 747-756.

Lassoued, I., Mora, L., Barkia, A., Aristoy, M. C., Nasri, M., \& Toldrá, F. (2015). Bioactive peptides identified in thornback ray skin's gelatin hydrolysates by proteases from Bacillus subtilis and bacillus amyloliquefaciens. Journal of Proteomics, 128, 8-17.

Lin, L., Yang, K., Zheng, L., Zhao, M., Sun, W., Zhu, Q., \& Liu, S. (2018). Anti-aging effect of sea cucumber (Cucumaria frondosa) hydrolysate on fruit flies and Dgalactose-induced aging mice. Journal of Functional Foods, 47, 11-18.

Mamelona, J., Saint-Louis, R., \& Pelletier, É. (2010a). Nutritional composition and antioxidant properties of protein hydrolysates prepared from echinoderm byproducts. International Journal of Food Science and Technology, 45(1), 147-154.

Mamelona, J., Saint-Louis, R., \& Pelletier, É. (2010b). Proximate composition and nutritional profile of by-products from green urchin and Atlantic Sea cucumber processing plants. International Journal of Food Science and Technology, 45(10), 2119-2126.

Mohan, A., \& Udenigwe, C. C. (2015). Towards the design of hypolipidaemic peptides: Deoxycholate binding affinity of hydrophobic peptide aggregates of casein plastein. Journal of Functional Foods, 18, 129-136.

Nalinanon, S., Benjakul, S., Kishimura, H., \& Shahidi, F. (2011). Functionalities and antioxidant properties of protein hydrolysates from the muscle of ornate threadfin bream treated with pepsin from skipjack tuna. Food Chemistry, 124(4), 1354-1362.

Nasri, R., Chataigné, G., Bougatef, A., Chaâbouni, M. K., Dhulster, P., Nasri, M., \& Nedjar-Arroume, N. (2013). Novel angiotensin I-converting enzyme inhibitory peptides from enzymatic hydrolysates of goby (Zosterisessor ophiocephalus) muscle proteins. Journal of Proteomics, 91, 444-452.

Nelson, E. J., MacDonald, B. A., \& Robinson, S. M. C. (2012). The absorption efficiency of the suspension-feeding sea cucumber, Cucumaria frondosa, and its potential as an extractive integrated multi-trophic aquaculture (IMTA) species. Aquaculture, 370-371, 19-25.

Neves, A. C., Harnedy, P. A., O’Keeffe, M. B., Alashi, M. A., Aluko, R. E., \& FitzGerald, R. J. (2017). Peptide identification in a salmon gelatin hydrolysate with antihypertensive, dipeptidyl peptidase IV inhibitory and antioxidant activities. Food Research International, 100, 112-120.

Ngo, D. H., Qian, Z. J., Ryu, B. M., Park, J. W., \& Kim, S. K. (2010). In vitro antioxidant activity of a peptide isolated from Nile tilapia (Oreochromis niloticus) scale gelatin in free radical-mediated oxidative systems. Journal of Functional Foods, 2(2), 107-117.
Nwachukwu, I. D., \& Aluko, R. E. (2019). A systematic evaluation of various methods for quantifying food protein hydrolysate peptides. Food Chemistry, $270,25-31$

Pacheco-Aguilar, R., Mazorra-Manzano, M. A., \& Ramírez-Suárez, J. C. (2008). Functional properties of fish protein hydrolysates from Pacific whiting (Merluccius productus) muscle produced by a commercial protease. Food Chemistry, 109(4), 782-789.

Panyam, D., \& Kilara, A. (1996). Enhancing the functionality of food proteins by enzymatic modification. Trends in Food Science \& Technology, 7(4), 120-125.

Pérez-Vega, J. A., Olivera-Castillo, L., \& Gómez-Ruiz, J. ángel, and HernándezLedesma, B. (2013). Release of multifunctional peptides by gastrointestinal digestion of sea cucumber (Isostichopus badionotus). Journal of Functional Foods, 5(2), 869-877.

Rao, P. S., Bajaj, R., \& Mann, B. (2020). Impact of sequential enzymatic hydrolysis on antioxidant activity and peptide profile of casein hydrolysate. Journal of Food Science and Technology. https://doi.org/10.1007/s13197-020-04495-2.

Rodríguez-Vázquez, R., Mato, A., López-Pedrouso, M., Franco, D., Sentandreu, M. A. , \& Zapata, C. (2020). Measuring quantitative proteomic distance between Spanish beef breeds. Food Chemistry, 315, 126293.

Roggatz, C. C., González-Wangüemert, M., Pereira, H., Rodrigues, M. J., da Silva, M. M., Barreira, L., ... Custódio, L. (2016). First report of the nutritional profile and antioxidant potential of Holothuria arguinensis, a new resource for aquaculture in Europe. Natural Product Research, 30(18), 2034-2040.

Saito, K., Jin, D. H., Ogawa, T., Muramoto, K., Hatakeyama, E., Yasuhara, T., \& Nokihara, K. (2003). Antioxidative properties of tripeptide libraries prepared by the combinatorial chemistry. Journal of Agricultural and Food Chemistry, 51(12), 3668-3674.

Sakanaka, S., \& Tachibana, Y. (2006). Active oxygen scavenging activity of eggyolk protein hydrolysates and their effects on lipid oxidation in beef and tuna homogenates. Food Chemistry, 95(2), 243-249.

Sakanaka, S., Tachibana, Y., \& Okada, Y. (2005). Preparation and antioxidant properties of extracts of Japanese persimmon leaf tea (kakinoha-cha). Food Chemistry, 89(4), 569-575.

Senadheera, T. R. L., Dave, D., \& Shahidi, F. (2020). Sea cucumber derived type I collagen : A comprehensive review. Marine Drugs, 18, 471.

Shahidi, F. (1994). Seafood proteins and preparation of protein concentrates. In F. Shahidi, \& J. R. Botta (Eds.), Seafoods: Chemistry, processing technology and quality. Boston, MA: Springer.

Shahidi, F., Han, X.-Q., \& Synowiecki, J. (1995). Production and characteristics of protein hydrolysates from capelin (Mallotus villosus). Food Chemistry, 53(3), 285-293.

Shahidi, F., \& Synowiecki, J. (1997). Protein hydrolyzates from seal meat as phosphate alternatives in food processing applications. Food Chemistry, 60(1), 29-32.

Shahidi, F., Varatharajan, V., Peng, H., \& Senadheera, R. (2019). Utilization of marine by-products for the recovery of value-added products. Journal of Food Bioactives, 6, 10-61.

Shahidi, F., \& Yeo, J. (2020). Should the in vitro colorimetric assays in antioxidant and lipid oxidation evaluation be abandoned?: A critical review focusing on bioactive molecule screening assays in in vitro and in vivo models. Journal of Food Bioactives, 9, 23-35.

Shahidi, F., \& Zhong, Y. (2008). Bioactive peptides. Journal of AOAC International, 91(4), 914-931.

Shahidi, F., \& Zhong, Y. (2015). Measurement of antioxidant activity. Journal of Functional Foods, 18, 757-781.

Slizyte, R., Rommi, K., Mozuraityte, R., Eck, P., Five, K., \& Rustad, T. (2016). Bioactivities of fish protein hydrolysates from defatted salmon backbones. Biotechnology Reports, 11, 99-109.

Sripokar, P., Benjakul, S., \& Klomklao, S. (2019). Antioxidant and functional properties of protein hydrolysates obtained from starry triggerfish muscle using trypsin from albacore tuna liver. Biocatalysis and Agricultural Biotechnology, 17, 447-454.

Thiansilakul, Y., Benjakul, S., \& Shahidi, F. (2007). Compositions, functional properties and antioxidative activity of protein hydrolysates prepared from round scad (Decapterus maruadsi). Food Chemistry, 103(4), 13851394.

Tripoteau, L., Bedoux, G., Gagnon, J., \& Bourgougnon, N. (2015). In vitro antiviral activities of enzymatic hydrolysates extracted from byproducts of the Atlantic holothurian Cucumaria frondosa. Process Biochemistry, 50(5), 867-875

Udenigwe, C. C., \& Aluko, R. E. (2012). Food protein-derived bioactive peptides: Production, processing, and potential health benefits. Journal of Food Science, 77(1), R11-R24 
Udenigwe, C. C., Udechukwu, M. C., Yiridoe, C., Gibson, A., \& Gong, M. (2016). Antioxidant mechanism of potato protein hydrolysates against in vitro oxidation of reduced glutathione. Journal of Functional Foods, 20, 195-203.

Villanueva, A., Vioque, J., Sânchez-Vioque, R., Clémente, A., Pedroche, J., Bautista, J., \& Millan, F. (1999). Peptide characteristics of sunflower protein hydrolysates. JAOCS, Journal of the American Oil Chemists' Society, 76(12), 1455-1460.

Wasswa, J., Tang, J., Gu, X. H., \& Yuan, X. Q. (2007). Influence of the extent of enzymatic hydrolysis on the functional properties of protein hydrolysate from grass carp (Ctenopharyngodon idella) skin. Food Chemistry, 104(4), 1698-1704.

Wettasinghe, M., \& Shahidi, F. (1999). Antioxidant and free radical-scavenging properties of ethanolic extracts of defatted borage (Borago officinalis L.) seeds. Food Chemistry, 67(4), 399-414.

Wijeratne, S. S. K., Abou-Zaid, M. M., \& Shahidi, F. (2006). Antioxidant polyphenols in almond and its coproducts. Journal of Agricultural and Food Chemistry, 54(2), 312-318.

Wong, F. C., Xiao, J., Ong, M. G. L., Pang, M. J., Wong, S. J., Teh, L. K., \& Chai, T. T. (2019). Identification and characterization of antioxidant peptides from hydrolysate of blue-spotted stingray and their stability against thermal, $\mathrm{pH}$ and simulated gastrointestinal digestion treatments. Food Chemistry, 271, 614-622.

Wouters, A. G. B., Rombouts, I., Fierens, E., Brijs, K., \& Delcour, J. A. (2016). Relevance of the functional properties of enzymatic plant protein Hydrolysates in food systems. Comprehensive Reviews in Food Science and Food Safety, 15(4), 786-800.

Xie, J., Du, M., Shen, M., Wu, T., \& Lin, L. (2019). Physico-chemical properties, antioxidant activities and angiotensin-I converting enzyme inhibitory of protein hydrolysates from Mung bean (Vigna radiate). Food Chemistry, 270, 243-250.

Xu, Q., Hong, H., Wu, J., \& Yan, X. (2019). Bioavailability of bioactive peptides derived from food proteins across the intestinal epithelial membrane: A review. Trends in Food Science and Technology, 86, 399-411.

Xu, Y., Galanopoulos, M., Sismour, E., Ren, S., Mersha, Z., Lynch, P., \& Almutaimi, A. (2020). Effect of enzymatic hydrolysis using endo- and exo-proteases on secondary structure, functional, and antioxidant properties of chickpea protein hydrolysates. Journal of Food Measurement and Characterization, 14(1), 343-352

Yan, M., Tao, H., \& Qin, S. (2016). Effect of enzyme type on the antioxidant activities and functional properties of enzymatic Hydrolysates from sea cucumber (Cucumaria frondosa) viscera. Journal of Aquatic Food Product Technology, 25(6), 940-952.

You, L., Zhao, M., Regenstein, J. M., \& Ren, J. (2010). Changes in the antioxidant activity of loach (Misgurnus anguillicaudatus) protein hydrolysates during a simulated gastrointestinal digestion. Food Chemistry, 120, 810-816.

Zhang, Y., He, S., Bonneil, É., \& Simpson, B. K. (2020). Generation of antioxidative peptides from Atlantic Sea cucumber using alcalase versus trypsin: In vitro activity, de novo sequencing, and in silico docking for in vivo function prediction. Food Chemistry, 306, 125581.

Zhong, Y., Khan, M. A., \& Shahidi, F. (2007). Compositional characteristics and antioxidant properties of fresh and processed sea cucumber (Cucumaria frondosa). Journal of Agricultural and Food Chemistry, 55(4), 1188-1192.

\section{Publisher's Note}

Springer Nature remains neutral with regard to jurisdictional claims in published maps and institutional affiliations.

\section{Ready to submit your research? Choose BMC and benefit from}

- fast, convenient online submission

- thorough peer review by experienced researchers in your field

- rapid publication on acceptance

- support for research data, including large and complex data types

- gold Open Access which fosters wider collaboration and increased citations

- maximum visibility for your research: over $100 \mathrm{M}$ website views per year

At BMC, research is always in progress.

Learn more biomedcentral.com/submissions 